\title{
I Want to (Bud) Break Free: The Potential Role of DAM and SVP-Like Genes in Regulating Dormancy Cycle in Temperate Fruit Trees
}

Vitor da Silveira Falavigna, Baptiste Guitton, Evelyne Costes and Fernando Andrés*

Amélioration Génétique et Adaptation des Plantes Méditerranéennes et Tropicales, Université de Montpellier, Centre de Coopération Internationale en Recherche Agronomique pour le Développement, Institut National de la Recherche Agronomique, Montpellier SupAgro, Montpellier, France

OPEN ACCESS

Edited by:

Michael James Considine, University of Western Australia, Australia

Reviewed by: David Horvath,

United States Department of Agriculture, United States Hisayo Yamane,

Kyoto University, Japan

Erika Varkonyi-Gasic

The New Zealand Institute for Plant \& Food Research Ltd., New Zealand

*Correspondence:

Fernando Andrés fernando.andres-lalaguna@inra.fr

Specialty section: This article was submitted to Plant Physiology, a section of the journa Frontiers in Plant Science

Received: 23 June 2018 Accepted: 20 December 2018 Published: 10 January 2019

Citation:

Falavigna VS, Guitton B, Costes E and Andrés F (2019) I Want to (Bud) Break Free: The Potential Role of DAM and SVP-Like Genes in Regulating Dormancy Cycle

in Temperate Fruit Trees.

Front. Plant Sci. 9:1990. doi: 10.3389/fp/s.2018.01990
Bud dormancy is an adaptive process that allows trees to survive the hard environmental conditions that they experience during the winter of temperate climates. Dormancy is characterized by the reduction in meristematic activity and the absence of visible growth. A prolonged exposure to cold temperatures is required to allow the bud resuming growth in response to warm temperatures. In fruit tree species, the dormancy cycle is believed to be regulated by a group of genes encoding MADS-box transcription factors. These genes are called DORMANCY-ASSOCIATED MADS-BOX (DAM) and are phylogenetically related to the Arabidopsis thaliana floral regulators SHORT VEGETATIVE PHASE (SVP) and AGAMOUS-LIKE 24. The interest in DAM and other orthologs of SVP (SVP-like) genes has notably increased due to the publication of several reports suggesting their role in the control of bud dormancy in numerous fruit species, including apple, pear, peach, Japanese apricot, and kiwifruit among others. In this review, we briefly describe the physiological bases of the dormancy cycle and how it is genetically regulated, with a particular emphasis on DAM and SVP-like genes. We also provide a detailed report of the most recent advances about the transcriptional regulation of these genes by seasonal cues, epigenetics and plant hormones. From this information, we propose a tentative classification of DAM and SVP-like genes based on their seasonal pattern of expression. Furthermore, we discuss the potential biological role of DAM and SVP-like genes in bud dormancy in antagonizing the function of FLOWERING LOCUS $T$-like genes. Finally, we draw a global picture of the possible role of DAM and SVP-like genes in the bud dormancy cycle and propose a model that integrates these genes in a molecular network of dormancy cycle regulation in temperate fruit trees.

Keywords: phenology, bud dormancy, SVP-like genes, bud break, seasonal, temperate tree species, MADS-box family transcription factors

\section{DESCRIPTION OF BIOLOGICAL PHENOMENON DURING DORMANCY CYCLE}

Temperate trees are distributed over a geographical zone of the globe that spans between the tropics and the polar regions. These regions present wide temperature ranges and seasonal changes all over the year. To survive these conditions, trees adjust their annual growth cycle to the seasonal environmental changes: they grow during the favorable seasons and progressively stop 
their growing activity, until the growth cessation of all meristems during the unfavorable ones (Figure 1). This plasticity is possible thanks to mechanisms of environment perception (i.e., day-length and temperature) and signaling pathways that are integrated in developmental programs. One crucial developmental program that allows adaptation to the low temperatures of winter is dormancy. In many of these species, dormancy is induced by the shortening of the day length that preludes the advent of the winter (Kramer, 1936). Dormancy can be defined as "a state of self-arrest of the shoot apical meristem (SAM) which is maintained under growthpromoting conditions" (Paul et al., 2014). However, it must be noted that dormancy also concerns buds that do not contain meristematic tissues any more, such as floral buds in Prunus species that contain a single flower. Lang et al. (1987) proposed that dormancy in temperate trees can be divided in three phases: paradormancy, endodormancy and ecodormancy. Paradormancy, also known as inhibition by correlation (Champagnat, 1989; Crabbe and Barnola, 1996), consists in the inhibition of growth regulated by hormones and competition among organs. In this stage, buds are competent to grow if separated from other parts of the plant. At the end of the autumn, the reduction of the photoperiod and the exposure to low temperatures induce growth cessation in all SAM and the formation of winter buds that protect the meristematic tissues, and thereafter endodormancy. During endodormancy, bud growth is inhibited by internal signals, and it is only overcome by a period of chilling temperatures (Lang et al., 1987; Anderson, 2015). It is associated with the mobilization of sugars and acquisition of cold hardiness. The amount of cold needed to release endodormancy, usually referred to as chilling requirement (CR), is species- and cultivar-dependent suggesting a strong genetic control of the trait (Olukolu et al., 2009; Falavigna et al., 2015). Once endodormancy is released, buds enter into ecodormancy during which they are competent to resume growth if experiencing warm conditions (Figure 1). However, bud growth's reactivation is inhibited as long as environmental conditions remain temporary unfavorable (e.g., cold temperatures) and is initiated after a period of increasing temperatures and after a sufficient amount of heat (referred as heat requirement, HR).

Environmental conditions (e.g., temperature and photoperiod) are perceived by plants through complex molecular networks and endogenous signals (e.g., plant hormones, oxidative stresses and energy metabolism) that regulate growth and dormancy cycle (i.e., growth cessation, dormancy phases and budbreak) in the SAM and more generally in buds. These networks have been studied in detail in SAM of some tree species, such as birch and poplar (see Singh et al., 2017). In response to short days, the symplasmic intracellular communication in the SAM is blocked by the deposition of callose (1,3- $\beta$-glucan) in the plasmodesmata. It is believed that the blockage of the SAM symplasmic paths restricts the transport of growth regulators, including orthologs of the Arabidopsis [Arabidopsis thaliana (L.) Heynh] FLOWERING LOCUS T (FT) protein (Rinne et al., 2011; Andrés and Coupland, 2012; Tylewicz et al.,

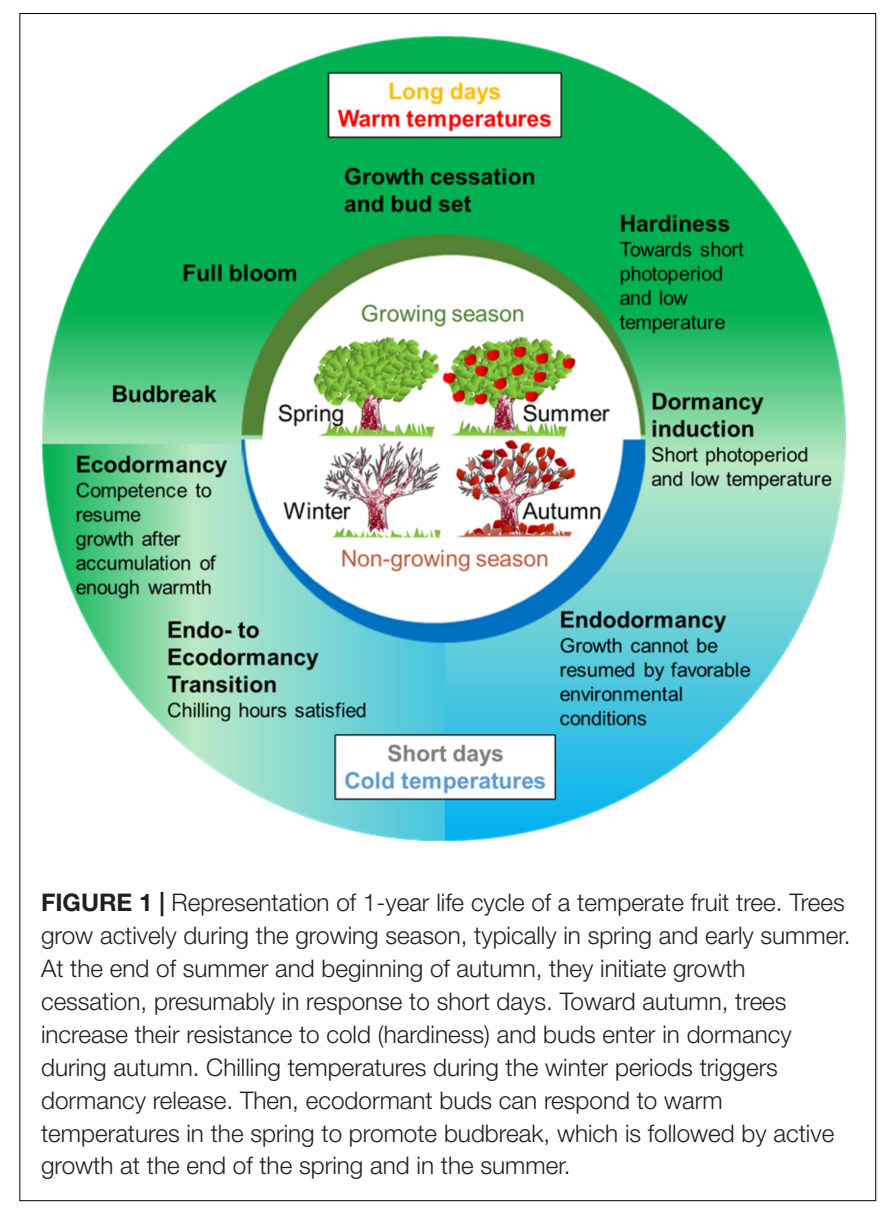

2018), leading to growth arrest and eventually to dormancy (Rinne and van der Schoot, 1998; Rinne and Kaikuranta, 2001). Recently, it was shown that the plant hormone abscisic acid (ABA) accumulates in response to short days in the SAM and contributes to plasmodesmata closure (Tylewicz et al., 2018). However, whether ABA influences this process by directly affecting callose deposition remains unclear. As mentioned above, endodormancy can be overcome by period of exposure to low temperature. Indeed, such temperature promotes the expression of genes encoding a subset of glucan hydrolase 17 (GH17) family members. The expression of these genes is correlated with the removal of the callose deposition from the plasmodesmata, and the consequent reactivation of the symplastic connectivity and the SAM growth (probably by allowing the transport of FT, among other growth-promoting substances, to the SAM) (Rinne et al., 2011). Interestingly, the exogenous application of the plant hormone gibberellin (GA) can replace low temperatures in dormancy release and induce the expression of specific GH17 genes (Rinne et al., 2011), suggesting a role of GA in this process. Other signals may be also involved in dormancy release and budbreak. In grapevine, the meristem isolation during dormancy triggers a series of hypoxia responses, including starch hydrolysis (Rubio et al., 2014) and signaling cascades (Meitha et al., 2015, 2018), that ultimate in dormancy release and budbreak. 
Compared to birch and poplar, our knowledge about dormancy cycle regulation by molecular mechanisms is much more limited in temperate fruit species. In these species temperature is the major factor affecting dormancy release and budbreak (Cook and Jacobs, 1999; Heide and Prestrud, 2005; Guo et al., 2014; Li et al., 2016) and therefore, they are extremely vulnerable to global warming. Temperature influences the tree phenology in the orchards by affecting winter cold fulfillment and the timing of growth resumption after dormancy. Perturbations of the dormancy cycle are already visible in changes of the time of budbreak, flowering synchronization between cultivars with consequences regarding reduction of the yield (Luedeling et al., 2011; Legave et al., 2013, 2015; Guo et al., 2015). However, the negative consequences for fruit tree production could be reduced or even nullified by adapting the CR of varieties to temperature changes at regional scale. Thus, the understanding of the dormancy cycle, its relationship to environmental factors and its molecular control is crucial to characterize existing cultivars and to obtain new ones better adapted to future scenarios of temperature increase. For this reason, an important effort on the understanding of the genetic and molecular control of dormancy cycle has been made during the last years.

In this review, we focus in the current knowledge of the molecular control of dormancy cycle mainly (but not solely) in temperate fruit tree species. Specifically, we focus on a group of genes that recently emerged as potential regulators of the dormancy cycle in these tree species. These genes were first identified more than 10 years ago and named as DORMANCYASSOCIATED MADS-BOX (DAM) genes (Bielenberg et al., 2008; Horvath et al., 2008). They were found phylogenetically related to the Arabidopsis floral regulators SHORT VEGETATIVE PHASE (SVP) and AGAMOUS-LIKE 24 (AGL24). In what follows, we discuss the discovery of $D A M$ genes, their most important structural and evolutionary features, how they are transcriptionally regulated, and how they might control the dormancy cycle. For obtaining a more global picture of dormancy regulation, the readers could also refer, among others, to any of these previous reviews: Rohde and Bhalerao (2007), Campoy et al. (2011), Cooke et al. (2012), Considine and Foyer (2014), Shim et al. (2014), Paul et al. (2014), Maurya and Bhalerao (2017), and Beauvieux et al. (2018).

\section{THE GENETIC DETERMINISM OF BUD DORMANCY IS ASSOCIATED WITH THE DAM GENES}

The study of the bud dormancy cycle gained a huge attention in the last two decades especially due to the agronomical disorders caused by global warming. New genetic and molecular tools were combined to the employment of natural mutants, contrasting cultivars and observation of phenological stages, rendering the first advances in the field. One of the most emblematic studies made use of the peach [Prunus persica (L.) Batsch] mutant called evergrowing (evg), which fails to form terminal vegetative buds and maintains constant growth in response to dormancyinducing conditions. The evg trait is genetically heritable and segregates as a single recessive gene (Rodriguez-A et al., 1994). The evg locus was tracked to peach linkage group 1 (LG1), and further mapping and sequencing of the locus revealed a genomic deletion affecting six tandemly repeated $\mathrm{MIKC}^{\mathrm{c}}$-type MADS-box genes, which were named PpeDAM1 to PpeDAM6 (Bielenberg et al., 2008). While PpeDAM1 to PpeDAM4 were physically deleted, the expression levels of PpeDAM5 and PpeDAM6 were reduced in the evg mutant (Bielenberg et al., 2008). Comparisons to the model plant Arabidopsis showed that DAM genes share sequence homology to $S V P$, and are sometimes referred to as $S V P$-like genes. Additional genetic studies in peach identified several minor quantitative trait locus (QTL) associated with bud dormancy, but the most significant QTL for CR usually overlapped with the evg locus (Fan et al., 2010; Romeu et al., 2014; Zhebentyayeva et al., 2014; Bielenberg et al., 2015). These results suggested that the DAM genes might be one of the most relevant genetic elements underlying CR in peach. In Japanese apricot (Prunus mume Sieb. et Zucc.), genomic library screening and shotgun sequencing revealed a peachlike genome structure, with six homologs of PpeDAM genes tandemly arrayed (Sasaki et al., 2011). Moreover, genetic analyses for CR, HR and PmuDAM6 expression identified a QTL in LG4, suggesting that this locus may control dormancy release, budbreak and PmuDAM6 downregulation in Japanese apricot leaf buds (Kitamura et al., 2018). In other Prunus species, the genetic determinisms of CR and flowering time were revealed, with QTLs coinciding with the location of DAM genes in almond [Prunus dulcis (Miller) D. A. Webb], apricot (Prunus armeniaca L.) and sweet cherry (Prunus avium L.) (Olukolu et al., 2009; Sánchez-Pérez et al., 2012; Castède et al., 2015). However, the most significant QTLs for these species were found in other loci, highlighting the complex genetic control of these characters. These findings suggest that DAM genes may be involved in the control of CR and flowering time in other Prunus species besides peach, although other genes possibly involved still have to be unveiled.

Genetic studies in apple (Malus x domestica Borkh.) and pear (Pyrus communis L.) also identified QTLs for budbreak and flowering time overlapping with $D A M$ genes. In apple, the employment of a multifamily and pedigree-based analysis revealed QTLs that co-localize with DAM genes in LG8 and LG15 (Allard et al., 2016), although the most recurrent QTL in apple is in LG9 (van Dyk et al., 2010; Celton et al., 2011; Urrestarazu et al., 2017). The QTLs in LG9 and LG8 were also identified in pear, consistently with the high synteny between the species (Gabay et al., 2017). Indeed, the genomes of Malus and Pyrus are highly syntenic, especially because they underwent a recent whole-genome duplication (WGD) event that is not shared with other Rosaceae clades such as the one that Prunus belongs to (Xiang et al., 2017). In apple, the genomic composition of $D A M$ genes were identified, but the number of detected $D A M$ genes was not consistent among reports (Mimida et al., 2015; Wisniewski et al., 2015; Kumar et al., 2016). Porto et al. (2016) proposed a unified nomenclature composed of four apple DAM genes (MdoDAM1 to MdoDAM4) and two SVP/JOINTLESS (J)-like genes, although not all genes previously named as $D A M$ were considered. A recent study 
functionally characterized MdoDAMb (Wu et al., 2017a), a gene that was excluded from this unified nomenclature due to bad gene prediction in the first apple genome version (Velasco et al., 2010). In Japanese pear (Pyrus pyrifolia Nakai), three DAM genes (called PpyMADS13 by the authors) were identified by PCR amplification using primers based on the sequence of PpeDAM6 (Ubi et al., 2010; Saito et al., 2013). By exploring the availability of the Chinese white pear (Pyrus bretschneideri Rehd.) genome, three DAM genes were identified and named PpyDAM1-3 (Niu et al., 2016). In both apple and pear, $D A M$ genes have close chromosomal locations and are present in the syntenic chromosomes 8 and 15. Interestingly, apple chromosome 8 is highly syntenic to the end of the peach chromosome 1 (Porto et al., 2016), where PpeDAM genes are located. This suggests that the recent WGD event shared by apples and pears generated two tandem regions containing DAM genes in these species. Tandem regions per se are difficult to map and annotate, and this partially explains why different studies found distinct quantities of DAM members in these species.

Besides Rosaceous species, DAM and SVP-like genes were also identified and related to dormancy cycle in other species. In the herbaceous perennial weed leafy spurge (Euphorbia esula L.), two EesDAM transcripts were identified (Horvath et al., 2008, 2010), but further characterization demonstrated that these transcripts result from alternative splicing of a single EesDAM gene (Horvath et al., 2013). Four genes similar to SVP were identified in the perennial kiwifruit vine (Actinidia spp.) (Wu et al., 2012). Recently, a gene called SVL (SHORT VEGETATIVE PHASE-LIKE) was identified in hybrid aspen (Populus tremula L. $\times$ P. tremuloides Michx.) and related to the regulation of budbreak (Singh et al., 2018).

\section{STRUCTURE AND PHYLOGENY OF DAM AND SVP-LIKE PROTEINS}

The DAM proteins belong to the plant exclusive type II MADS-box transcription factors called MIKC ${ }^{\mathrm{c}}$, which present a characteristic arrangement of four major domains (Figure 2). The MADS-box domain is involved in DNA binding, while the I and $\mathrm{K}$ domains are essential for protein dimerization and higherorder complex formations (Kaufmann et al., 2005). The role of the $\mathrm{C}$ region is less clear and may be involved in protein complex formation and transcriptional regulation (Smaczniak et al., 2012). The MIKC ${ }^{\mathrm{c}}$ transcription factors are divided into 13 subfamilies originated from ancestral seed plants (Smaczniak et al., 2012). Phylogenetic and molecular evolution analysis of the DAM genes classified them as belonging to the StuMADS11/AGL24/SVP subfamily of MADS-box transcription factors (Jiménez et al., 2009).

A new simplified phylogeny is proposed for DAM and SVP-like proteins (Figure 2), in order to represent previously published data, as well as to update the information based on recent findings. For apple DAMs, we followed the nomenclature proposed by Porto et al. (2016), while for Japanese pear we followed the nomenclature proposed by Ubi et al. (2010) and Saito et al. (2013), with an additional DAM identified by Niu et al. (2016) referred as PpyDAM3. The proteins grouped into two major clusters (Figure 2). All Rosaceous DAM proteins formed a cluster subdivided in two groups; one containing Prunus DAM proteins and other from Malus and Pyrus (Figure 2). This highlights the evolutionary similarities of these Rosaceous genera, but at the same time the differences among genus. Another well-defined cluster was composed of SVP-like proteins of Arabidopsis, apple, Japanese apricot, kiwifruit, peach, and Japanese pear, together with leafy spurge DAM proteins. The segregation of SVP-like proteins in a different cluster suggests an evolutionary diversification among DAM and SVP-like genes within Rosaceae. This could be interpreted as a process of neofunctionalization between $D A M$ and SVP-like genes, and subfunctionalization within the $D A M$ genes. The latter has been proposed for PpeDAM genes in peach (Jiménez et al., 2009; Li et al., 2009).

\section{EXPRESSION PATTERNS AND ENVIRONMENTAL CONTROL OF DAM AND SVP-LIKE GENES}

The quantification of $D A M$ transcript levels during the year has shown that their mRNA expression profiles correlate to different dormancy cycle phases. A summary of the transcriptomic studies that identified DAM genes differentially expressed during bud dormancy is presented in Table 1. Despite the employment of different quantification techniques and plant materials (e.g., apical or lateral buds, flower or vegetative buds, etc.), the DAM genes remarkably presented seasonal expression patterns along the year. Interestingly, these profiles were somehow consistent even among different species. Here, we clustered the expression patterns of DAM genes from several species (i.e., apple, Japanese pear, Japanese apricot, peach, sweet cherry, Chinese cherry, leafy spurge and kiwifruit) into three different groups based on their seasonal pattern of expression during the growth and dormancy cycle (Figure 3). Some Rosaceous genes do not show a consistent pattern of expression among different publications and thus, they are not included in Figure 3. Additionally, we excluded DAM and SVP-like genes from poplar (Howe et al., 2015) and tea plant (Hao et al., 2017), as their seasonal expression pattern did not fit in any of the proposed groups. Whether this indicates that these genes are not involved in dormancy cycle or have a different role in poplar and tea plant remains uncertain. We attempted to assign a function to the genes belonging to each group depending on the particular dormancy cycle phase during which their expression was maximal. This function was assigned based on the proposed role for a subset of genes of a given group that were already functionally characterized (see the section "What Do We Know About the Biological Function of DAM and SVPLike Genes?") and might not reflect the precise function of all the genes of the group. However, for many of the genes included in Figure 3, the expression profile is the only information present in the literature that could help us to infer their biological function. 


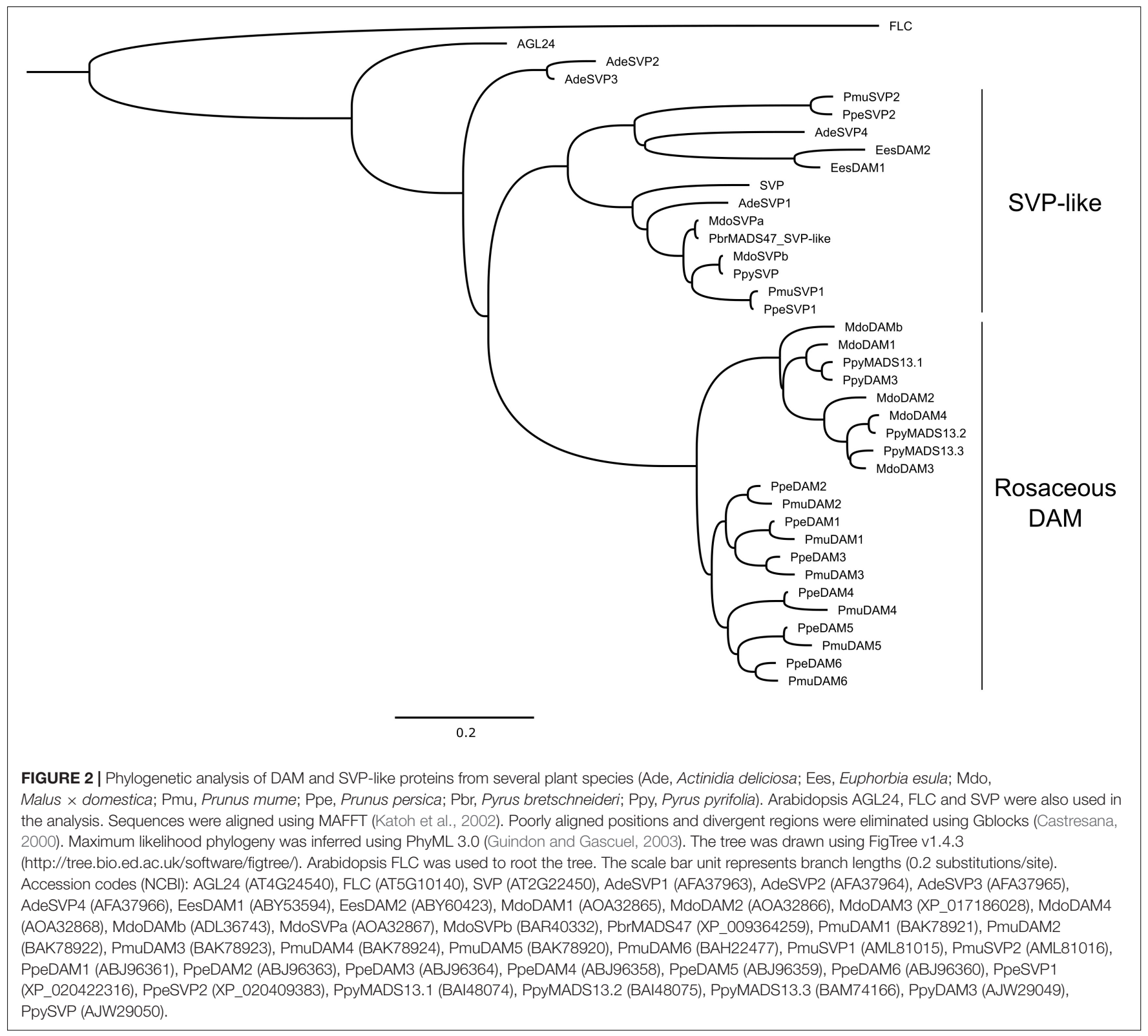

$D A M$ genes showing the expression pattern \#1 presented a peak of expression (approximately) during bud set, i.e., in the transition from summer to autumn (Figure 3). Peach genes displaying this pattern were proposed to have a role in the regulation of seasonal growth cessation and terminal bud formation (Li et al., 2009). As DAM genes from Japanese apricot (Sasaki et al., 2011; Zhao et al., 2018a), apple (Mimida et al., 2015; Wisniewski et al., 2015; Porto et al., 2016; Wu et al., 2017a) and leafy spurge (Horvath et al., 2008, 2013) showed a similar expression pattern, we can hypothesize that some of these genes may share the same role as the peach genes. A wide range of sampling materials were used to quantify these genes, such as terminal tissues (peach), lateral vegetative and floral buds (Japanese apricot), crown buds (leafy spurge), or apical buds and bark tissues (apple).
The vast majority of $D A M$ genes showed the expression pattern \#2, presenting their highest expression levels during endodormancy. Their subsequent transcriptional downregulation was correlated with the satisfaction of CR or HR. This pattern of expression is compatible with a role as quantitative repressors of endodormancy release and/or budbreak, as suggested for PmuDAM6 (Sasaki et al., 2011). The expression pattern \#2 was identified for DAM genes of Japanese apricot (Sasaki et al., 2011; Zhao et al., 2018a,b), peach (Li et al., 2009; Jiménez et al., 2010b; Yamane et al., 2011a,b,c), Japanese pear (Ubi et al., 2010; Liu et al., 2012; Bai et al., 2013; Saito et al., 2013; Ito et al., 2016; Niu et al., 2016), apple (Falavigna et al., 2014; Mimida et al., 2015; Wisniewski et al., 2015; Kumar et al., 2016, 2017; Porto et al., 2016; Wu et al., 2017a), sweet and Chinese cherry (Zhu et al., 2015; Rothkegel et al., 2017), 
TABLE 1 | Summary of transcriptome studies during dormancy, highlighting the ones that identified DAM and SVP-like genes.

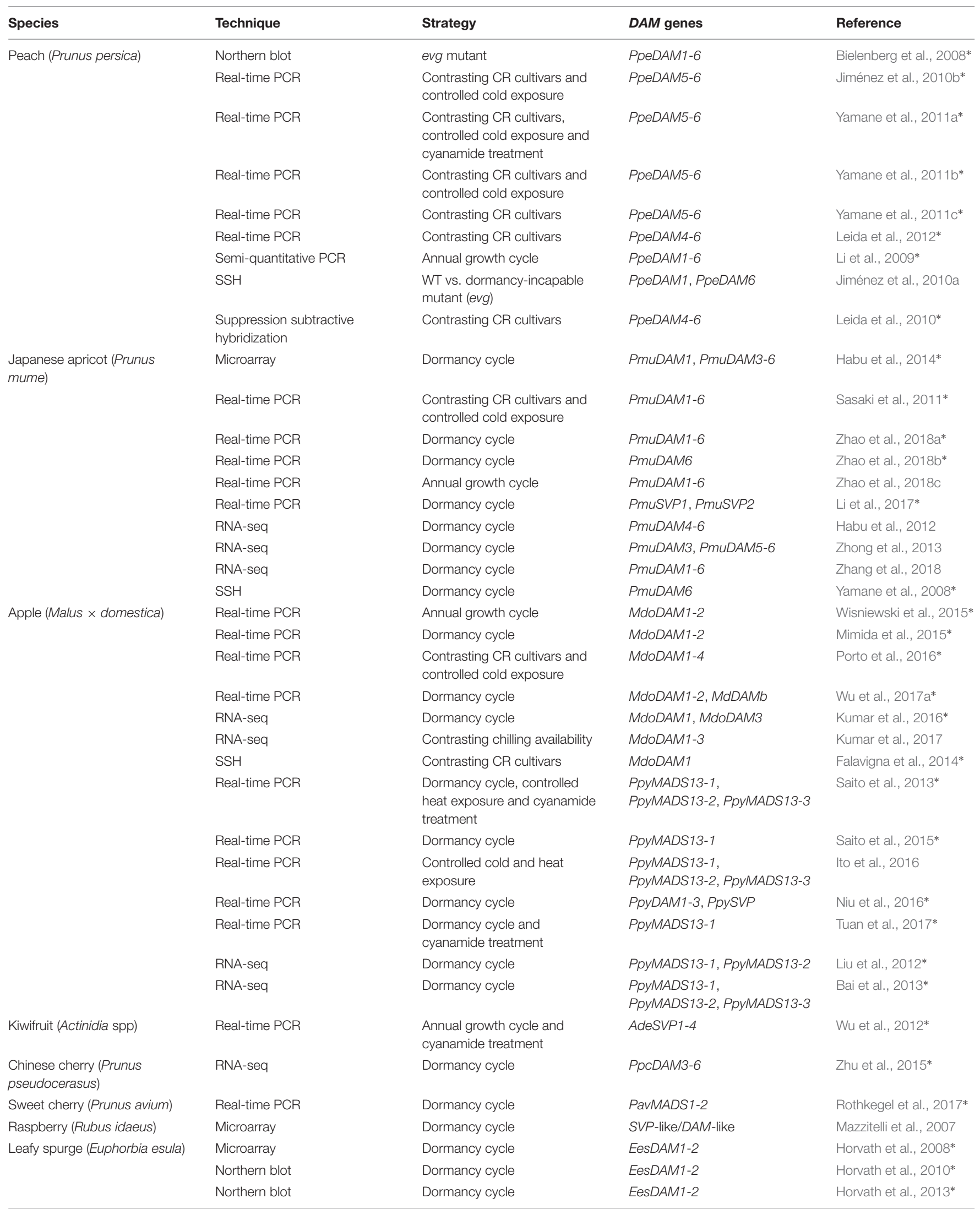


TABLE 1 | Continued

\begin{tabular}{|c|c|c|c|c|}
\hline Species & Technique & Strategy & $D A M$ genes & Reference \\
\hline & Real-time PCR & Dormancy cycle & EesDAM1-2 & Doğramaci et al., 2010* \\
\hline & Real-time PCR & Dormancy cycle & EesDAM1-2 & Hao et al., 2015* \\
\hline Poplar (Populus trichocarpa) & Microarray & Dormancy cycle & $D A M$-like & Howe et al., 2015 \\
\hline Tea (Camellia sinensis) & RNA-seq & Dormancy cycle & DAM-like & Hao et al., 2017 \\
\hline
\end{tabular}

*Studies used to build Figure 3. SSH, suppression subtractive hybridization.

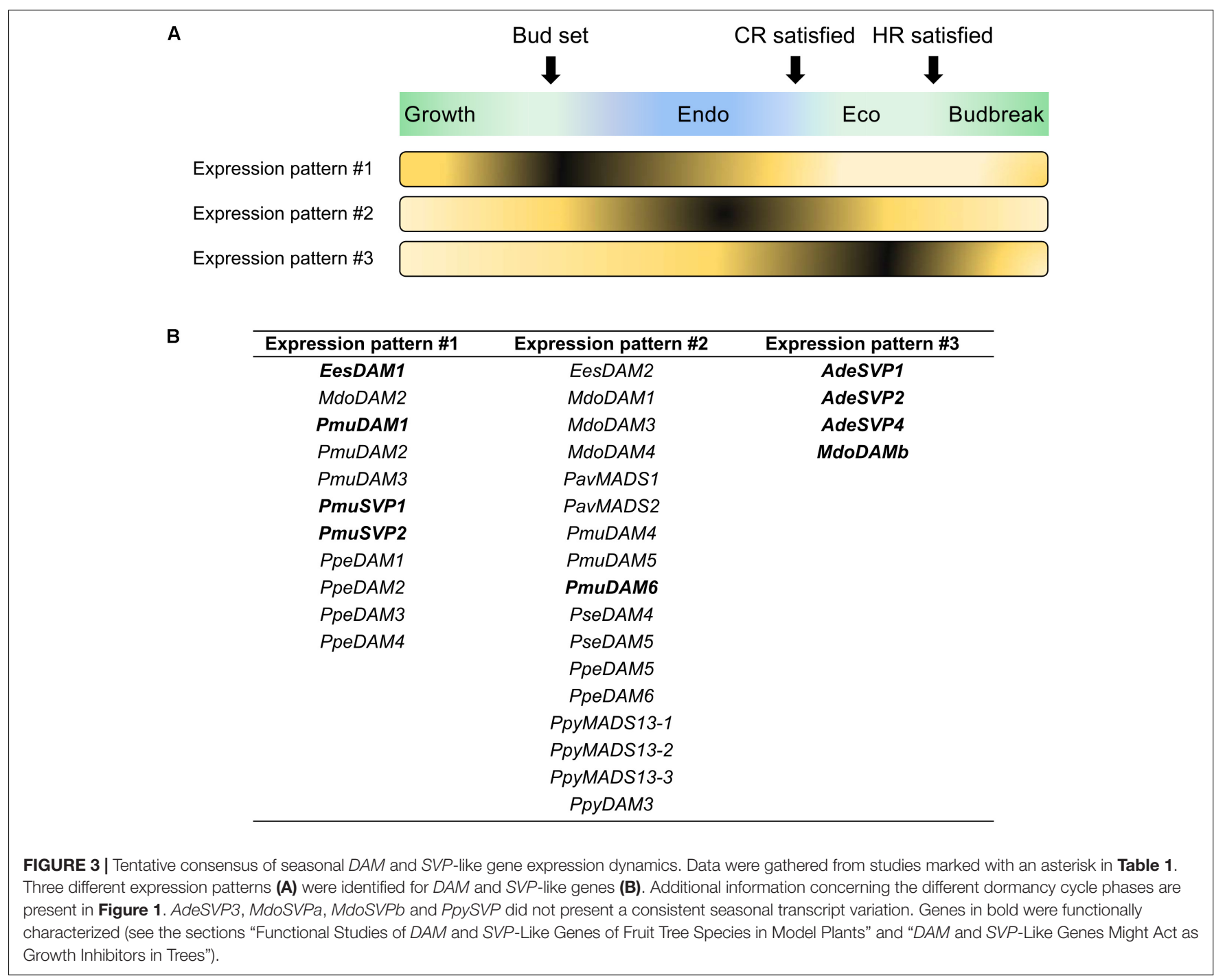

and leafy spurge (Horvath et al., 2008, 2013). Again, a wide range of tissues were employed in the quantification of these genes.

PpeDAM1/PpeDAM4 (expression pattern \#1) and PpeDAM5/PpeDAM6 (expression pattern \#2) are expressed when the day-length is short and the temperature is low. Interestingly, these genes were up-regulated in experiments where peach plants were transferred from long-days $(16 / 8 \mathrm{~h}$ light/dark) to short-days $(8 / 16 \mathrm{~h} \mathrm{light/dark})$ in controlled environments ( $\mathrm{Li}$ et al., 2009). To know if these genes are also induced by cold, peach branches sampled in the autumn were maintained in a constant $12 \mathrm{~h}$ light/dark photoperiod cycle and exposed to two temperature regimes: around $25^{\circ} \mathrm{C}$ or around $15^{\circ} \mathrm{C}$. The expression of PpeDAM5 and PpeDAM6 was up-regulated in lateral vegetative buds by the $15^{\circ} \mathrm{C}$ treatment (Yamane et al., 2011a). These experiments suggested that both short-days conditions and short-term low temperature exposure trigger the expression of these DAM genes. From these studies, it can be hypothesized that each $D A M$ gene could integrate distinct environmental signals (such as photoperiod and/or temperature) in order to allow a fine-tuning regulation of the different phases of tree dormancy cycle, with genes showing 


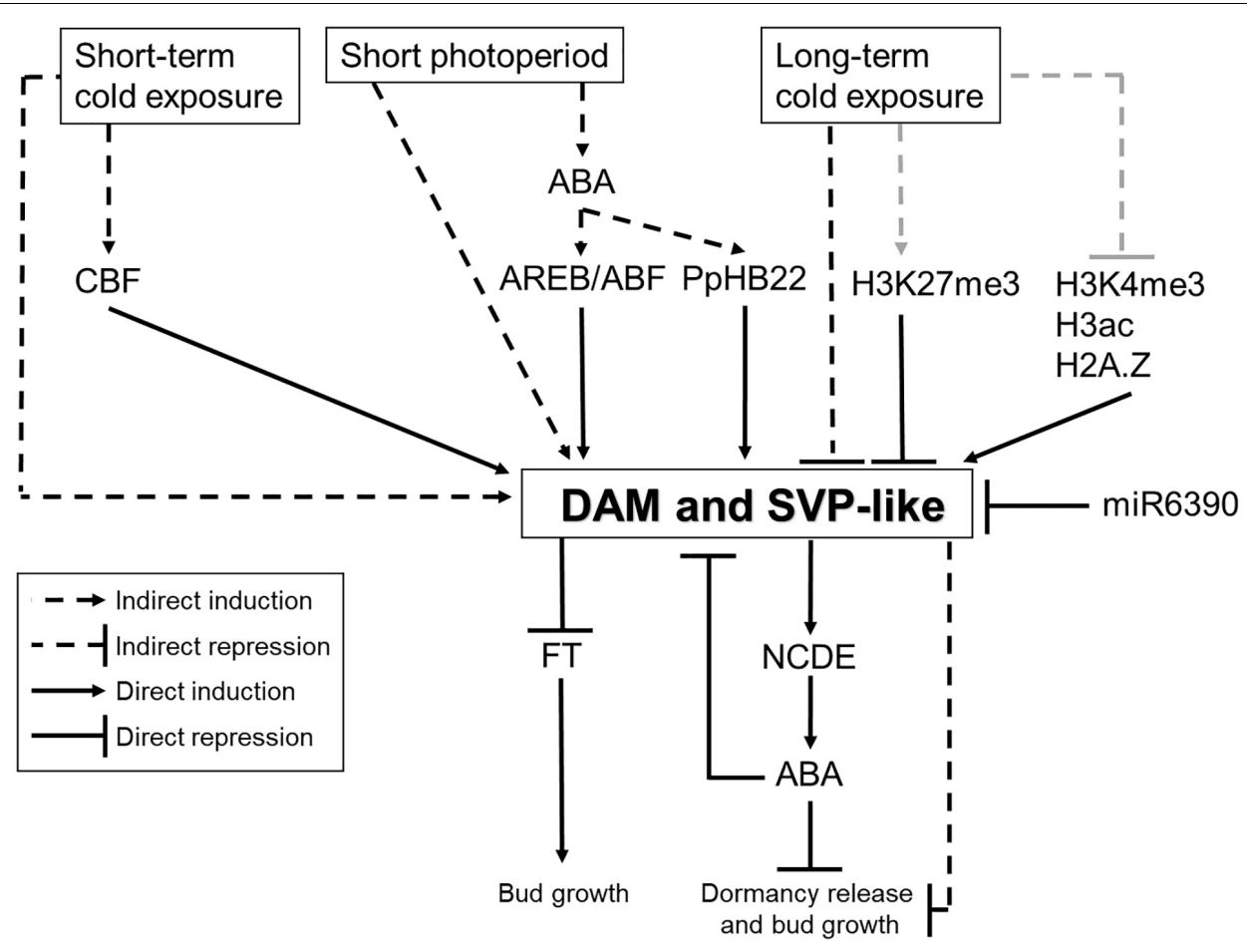

FIGURE 4 | A possible model of molecular control of bud dormancy in temperate fruit tree species mediated by DAM and SVP-like genes. It has been shown that $D A M$ and SVP-like genes are regulated by photoperiod and temperature. This regulation is probably mediated by several transcription factors, miRNAs, plant hormones and chromatin modifiers. In turn, DAM and SVP-like transcription factors are involved in the repression of bud growth, probably by affecting the expression of $F T$-like genes and ABA levels. Black lines indicate molecular connections based on previous reports. Gray lines indicate expected genetic interactions that have not been proved yet.

expression pattern \#1 involved in growth cessation and bud formation, and genes showing expression pattern \#2 more likely involved in endodormancy maintenance. Another common trend concerning $D A M$ genes responsiveness to environmental cues was observed after dormancy establishment, when twigs were exposed to prolonged cold temperatures in controlled conditions. This treatment led to the down-regulation of $D A M$ genes in a cultivar-dependent manner (i.e., cultivars with low CR repressed these genes earlier than cultivars with high CR) (Jiménez et al., 2010b; Sasaki et al., 2011; Yamane et al., 2011a; Porto et al., 2016). The reduction of DAM gene expression levels by prolonged cold temperatures might be part of a mechanism to control dormancy-release. Indeed, SVL regulates budbreak in hybrid aspen by antagonizing GA and ABA pathways (Singh et al., 2018), and its mRNA expression levels are negatively regulated by low temperatures. Still, further studies are necessary to clarify whether DAM genes from fruit tree species act as repressors of dormancy-release and/or budbreak.

Finally, DAM genes displaying the expression pattern \#3 presented highest expression levels before budbreak, usually in the early spring. This pattern was find for apple and kiwifruit genes (Wu et al., 2012, 2017a). Interestingly, two genes showing this pattern of expression ( $M d o D A M b$ and AdeSVP2) were already functionally characterized (see the section "DAM and SVP-Like Genes Might Act as Growth
Inhibitors in Trees"; Wu et al., 2017a,b), suggesting a putative role related to the maintenance of growth suppression upon dormancy establishment, preventing premature growth before budbreak.

\section{WHAT REGULATES THE TRANSCRIPTION OF DAM GENES?}

\section{A Possible Transcriptional Control of DAM Genes by the CBF Transcription Factors}

As shown above, the changes in DAMs gene expression are transcriptionally modulated by environmental cues. Potential regulators of DAMs transcription in response to environmental factors and especially to cold could be a group of transcription factors called dehydration-responsive elementbinding (DREB) protein/C-repeat binding factors (CBFs) (reviewed in Akhtar et al., 2012; Zhao et al., 2015) which have been described (Figure 4) as governing cold signaling. Indeed, the expression of these genes is rapidly induced in response to cold in order to increase plant tolerance to freezing stress (Akhtar et al., 2012; Zhao et al., 2015). In agreement with this function, the expression of some peach and Japanese apricot CBFs was shown to be induced by cold treatments 
(Wisniewski et al., 2015; Zhao et al., 2018c). Furthermore, the transcriptional profile of some $C B F$ had a maximum peak of expression during winter in Japanese pear (Mimida et al., 2015; Niu et al., 2016) and Japanese apricot (Zhao et al., 2018b).

Characteristically, CBF transcription factors recognize and bind to the CRT/DRE (C-repeat/dehydration responsive element) DNA regulatory motif in the promoters of coldresponsive genes (Zhao et al., 2015). The CRT/DRE motif were found in the promoter region of DAM genes in leafy spurge (Horvath et al., 2010), Japanese pear (Saito et al., 2015; Niu et al., 2016), apple (Mimida et al., 2015; Wisniewski et al., 2015) and Japanese apricot (Zhao et al., 2018b). Furthermore, the promoters of some DAM genes contain EVENING elements (Horvath et al., 2010), which are known to play a role in circadian regulation and cold induction mediated by CBF (Mikkelsen and Thomashow, 2009). These facts suggest a direct role of CBF transcription factor in controlling the expression levels of DAM genes mediated by cold. The experimental confirmation for the binding of $\mathrm{CBF}$ transcription factors to promoter regions of $D A M$ genes was reported for various temperate tree species. For example, yeast-one-hybrid (Y1H) experiments showed that $\mathrm{CBF}$ proteins interact with promoter regions containing CRT/DRE motifs of PpyDAM1 and PpyDAM3 in Japanese pear (Niu et al., 2016), and PmuDAM6 in Japanese apricot (Zhao et al., 2018b). Moreover, Japanese pear CBF transcription factors were able to induce the expression of PpyDAM1-1 and PpyMADS13-3 genes in transient reporter assays (Saito et al., 2015; Niu et al., 2016). The ectopic expression of a peach $\mathrm{CBF}(P p e C B F 1)$ in the apple rootstock variety M26 affected the expression levels of MdoDAM1 and MdoDAM3 (called $M d o S V P b$ in this review) in buds (Wisniewski et al., 2015). These transgenic trees showed a number of interesting phenotypes such as increased cold hardiness, early growth cessation and leaf senescence, delayed budbreak, growth inhibition, and increased sensitivity to short photoperiod with respect to the onset of dormancy (Wisniewski et al., 2011, 2015).

These data suggest that CBF could participate in the coldmediated transcriptional activation of DAM genes during endodormancy induction. Although this could be related to a mechanism of bud hardiness acquisition, it is reminiscent to the mechanism of flowering inhibition by intermittent-cold sensing that was proposed for Arabidopsis (Seo et al., 2009). In Arabidopsis, CBF transcription factors induce the expression of FLOWERING LOCUS C (FLC) in response to short periods of cold. Then, FLC acts as floral repressor and prevents flowering to occur under unfavorable conditions (Seo et al., 2009). The intermittent-cold sensing system differs from the vernalization process described in Arabidopsis and other Brassicaceae, where long exposure to cold triggers the epigenetic-mediated inhibition of FLC mRNA toward the end of winter, and allows flowering to happen in spring (Michaels and Amasino, 1999; Romera-Branchat et al., 2014). In a similar manner, it has been hypothesized that two mechanisms of cold sensing and signaling could operate during temperate tree dormancy cycle to control DAM expression (Horvath, 2009). One mechanism mediated by $\mathrm{CBF}$ would operate in direct response to cold at the beginning of winter to activate the transcription of some $D A M$ genes, whereas an independent mechanism might regulate the gradual silencing of $D A M$ genes upon exposure to low temperature.

\section{Epigenetic Mechanisms Regulating DAM Genes}

Recently, a significant amount of publications has specifically addressed how epigenetic mechanisms contribute to the regulation of complex traits including vernalization and bud dormancy (Ríos et al., 2014; Richards et al., 2017). During the winter vernalization in Arabidopsis, histone modifications related to active transcription such as histone $\mathrm{H} 3$ at lysine 4 (H3K4me3) are removed from the FLC locus (He et al., 2004). Instead, the FLC locus is decorated with trimethylation of histone $\mathrm{H} 3$ at K27 (H3K27me3) (Bastow et al., 2004), a mark associated with inactive transcription, by the action of the Polycomb Repressive Complex 2 (PRC2) (Whittaker and Dean, 2017). Histone modifications, changes in DNA methylation patterns, and the regulation imposed by small non-coding RNAs (siRNAs) were already observed during dormancy in several perennials (Leida et al., 2012; Zhang et al., 2012; de la Fuente et al., 2015; Saito et al., 2015; Tuan et al., 2016; Conde et al., 2017a,b; Guo et al., 2017; Rothkegel et al., 2017). However, just a few reports have directly analyzed the epigenetic mechanisms acting over DAM genes (Figure 4).

Epigenetic regulation of $D A M$ genes was first suggested by analyzing dormant buds of leafy spurge (Horvath et al., 2010). During the dormancy cycle, a decrease in the H3K4me3 pattern concomitant to an increase of $\mathrm{H} 3 \mathrm{~K} 27 \mathrm{me} 3$ was identified in two regions downstream of the transcription start site of EesDAM1 (Horvath et al., 2010). Interestingly, these changes in epigenetic marks were associated with the downregulation of EesDAM1 gene during the transition from endodormancy to ecodormancy (Figure 3). This suggests that the seasonality of $D A M$ expression in leafy spurge may be controlled in a manner that resembles the FLC repression during vernalization.

Further evidence of epigenetic regulation over $D A M$ genes was provided in peach. Similar chromatin modifications observed for EesDAM1 were identified for PpeDAM6 in two contrasting $\mathrm{CR}$ peach cultivars during dormancy transition, i.e., decrease of $\mathrm{H} 3 \mathrm{~K} 4 \mathrm{me} 3$ and increase of $\mathrm{H} 3 \mathrm{~K} 27 \mathrm{me} 3$ near the promoter, the translation start site and the largest intron (Leida et al., 2012). Moreover, a decrease in the acetylation levels of $\mathrm{H} 3$ ( $\mathrm{H} 3 \mathrm{ac}$ ) near dormancy release, an epigenetic mark that is related to activation of transcription, was shown. A significant enrichment of $\mathrm{H} 3 \mathrm{~K} 27 \mathrm{me} 3$ was also revealed at specific regions of this locus during dormancy release (de la Fuente et al., 2015), which could contribute to the differential transcription observed for PpeDAM genes during dormancy (Figure 3).

In sweet cherry, higher levels of DNA methylation were found in the promoters of PavMADS1 and PavMADS2 
after CR completion (Rothkegel et al., 2017). An increase in the abundance of small interfering RNAs (siRNA) was associated with the observed de novo DNA methylation in the promoter region of PavMADS1 (Rothkegel et al., 2017). DNA methylation and siRNAs are related to transcription repression when present at the promoter region, which suggests that these epigenetic changes modulate the down-regulation of DAM genes during dormancy.

In Japanese pear, the analysis of the chromatin status of PpyMADS13-1 identified a reduction of H3K4me3 prior to endodormancy release, but no differences were found to H3K27me3 during the dormancy cycle (Saito et al., 2015). Additionally, the authors analyzed the deposition of the histone variant $\mathrm{H} 2 \mathrm{~A} . \mathrm{Z}$, which in Arabidopsis is responsible to regulate gene expression according to ambient temperature (Kumar and Wigge, 2010). PpyMADS13-1 chromatin showed a tendency to lose H2A.Z during endodormancy release (Saito et al., 2015), and together with the concomitant down-regulation of this gene at this time point (Figure 3), it indicates that this histone variant may have a negative role over dormancy release.

\section{Regulatory Intronic Regions Could Be Relevant for the Transcriptional Control of DAM Genes}

One particular feature of some MADS-box genes is the presence of a long multi-thousand base intron, which usually contains several regulatory sequences that help in the control of gene expression. Several examples demonstrated how regulatory intronic regions control the expression of MADS-box genes such as AGAMOUS (AG) (Sieburth and Meyerowitz, 1997; Hong, 2003), AGAMOUS-LIKE 6 (AGL6) (Schauer et al., 2009), FLC (Gazzani et al., 2003; Liu et al., 2004; Heo and Sung, 2011), FLOWERING LOCUS M (FLM) (Lutz et al., 2015), among others. Especially for FLC, transposon insertions into its largest intron were shown to be responsible for the reduction of FLC expression in the early flowering Landsberg erecta accession (Gazzani et al., 2003; Liu et al., 2004). In peach, transposon-related insertions in the largest intron of PpeDAM5 and PpeDAM6 were observed in low CR cultivars (Yamane et al., 2011c; Zhebentyayeva et al., 2014), resembling FLC gene regulation. However, several Japanese pear genotypes with distinct CRs were screened for insertions in the largest intron of PpyMADS13-1, but no relationship with the dormancy cycle was found (Saito et al., 2013). Finally, a highly conserved sequence of nearly $200 \mathrm{bp}$ was identified inside the largest intron of apple, Japanese apricot, peach and Japanese pear DAM genes, and the sequence conservation was even higher than for some DAM exonic sequences (Porto et al., 2016). The evolutionary maintenance of this intronic region suggests a functional role in the transcriptional regulation of $D A M$ genes. Whether this region is required for the seasonal mRNA expression profile of DAM genes needs further studies.

\section{WHAT DO WE KNOW ABOUT THE BIOLOGICAL FUNCTION OF DAM AND SVP-LIKE GENES?}

\section{Functional Studies of DAM and SVP-Like Genes of Fruit Tree Species in Model Plants}

SVP is a main factor for Arabidopsis development. The lossof-function and ectopic expression of SVP conferred early and late flowering, respectively (Hartmann et al., 2000; Lee et al., 2007), indicating that SVP functions as a floral repressor during the vegetative phase. In the reproductive phase, SVP regulates the pattern of floral development together with AGL24 and APETALA1 (AP1) (Gregis et al., 2006). Several reports describing the biological function of DAM and SVP-like genes in perennial species evaluated their function in flowering time and organ development in heterologous systems. The ectopic expression of four kiwifruit $S V P$-like genes from the $35 S$ promoter in Arabidopsis plants led to abnormalities in inflorescences and floral structures, suggesting a similar role in reproductive development as the Arabidopsis SVP counterpart ( $\mathrm{Wu}$ et al., 2012). However, only AdeSVP1 and AdeSVP3 were able to delay flowering in Arabidopsis and complement the SVP lossof-function. None of the SVP-like genes complemented the agl24 mutant, which shows late flowering (Michaels et al., 2003), indicating that these genes share functional features with SVP but not with AGL24 (Wu et al., 2012). In Japanese apricot, the constitutive expression of PmuSVP1 and PmuSVP2 in Arabidopsis caused floral abnormalities, but only PmuSVP1 delayed flowering ( $\mathrm{Li}$ et al., 2017). Ectopic expression of EesDAM1 from leafy spurge in Arabidopsis plants slightly delayed flowering (Horvath et al., 2010).

The results presented above indicate that the misexpression of SVP-like genes in Arabidopsis causes similar phenotypes to those produced when SVP function is affected (i.e., shifting flowering time and causing floral development abnormalities). Therefore, it is possible to hypothesize that $S V P$-like genes have a molecular function similar to the one of the Arabidopsis SVP. However, they have obvious distinct roles in annual and tree species, i.e., control of floral induction and involvement in dormancy cycle, respectively, indicating a strong functional diversification of these genes during the evolution.

\section{DAM and SVP-Like Genes Might Act as Growth Inhibitors in Trees}

Ectopic expression of DAM and SVP-like genes was shown to have a growth inhibitory effect able to alter the dormancy cycle in comparison to non-transgenic plants (Figure 4). Different $D A M$ and SVP-like genes may play distinct roles during different dormancy cycle phases. The constitutive expression of PmuDAM6 (expression pattern \#2) in poplar induced growth cessation, bud set and bud endodormancy (Sasaki et al., 2011). From this result, it is possible to suggest that this gene, and probably other $D A M$ genes having expression pattern \#2, play a critical function in endodormancy regulation. On the other 
hand, a weaker effect was observed in poplar trees expressing PmuDAM1, which seemed to promote and inhibit apical growth depending on the growth conditions (Yamane and Tao, 2015). In kiwifruit, the overexpression of AdeSVP2 delayed budbreak of lateral floral buds in the high-chill cultivar A. deliciosa, but did not affect growth cessation, leaf drop, timing of bud-set and bud formation (Wu et al., 2017b). The delay in budbreak could be overcome by exposing these transgenic vines to long periods of cold. Moreover, the AdeSVP2 overexpression had no effect on a low chilling kiwifruit species (A. eriantha). In the light of these results, the role of AdeSVP2 appears unrelated to cold-mediated dormancy release, but its function could be to prevent premature growth (Wu et al., 2017b). This growth inhibitory function was also observed in transgenic tobacco plants ectopically expressing AdeSVP2 (Wu et al., 2017b). In apple, transgenic trees overexpressing $M d o D A M b$ and $M d o S V P a$ showed delayed budbreak without displaying any additional phenotype related to leaf senescence and bud set (Wu et al., 2017a). With the exception of PmuDAM6, the other DAM and SVP-like genes functionally characterized so far seem to be involved in repressing growth after dormancy establishment and/or budbreak after dormancy release rather than promoting bud set and endodormancy.

\section{DAM and SVP-Like Genes Might Antagonize FT-Like Functions}

MADS-box proteins are commonly involved in the control of developmental switches such as floral transition (Andrés and Coupland, 2012) and the specification of floral organ identity (Theißen et al., 2016). In Arabidopsis, SVP regulates the reproductive development mainly by acting as a transcriptional repressor in distinct flowering and hormonal-signaling pathways (Gregis et al., 2013). Notably, it delays flowering by the direct repression of the floral integrators FT and SUPPRESSOR OF OVEREXPRESSION OF CONSTANS (SOC1) under non-inductive conditions ( $\mathrm{Li}$ et al., 2008; Jang et al., 2009). The protein encoded by FT shares high homology with mammalian phosphatidylethanolamine-binding proteins (PEBPs) (Kardailsky et al., 1999; Kobayashi et al., 1999), and in many plant species it functions as a main component of the long-distance signal that induces flowering (and therefore named "florigen") (Corbeer et al., 2007; Jaeger and Wigge, 2007; Mathieu et al., 2007; Tamaki et al., 2007). The ectopic overexpression of orthologs of FT (FT-like genes) from several temperate fruit species such as apple, peach, sweet cherry, Japanese apricot and kiwifruit accelerates flowering in Arabidopsis (Kotoda et al., 2010; Tränkner et al., 2010; Varkonyi-Gasic et al., 2013; Yarur et al., 2016). This suggests a conserved function of this gene across taxes (Pin and Nilsson, 2012).

The function of FT-like genes has been suggested to be linked to bud dormancy in temperate trees. For instance, the misexpression of poplar FT homologs significantly alters growth cessation, bud set and dormancy entrance (Böhlenius et al., 2006; Hsu et al., 2011). Moreover, the ectopic expression of FT from Populus trichocarpa (PtrFT1) in plum also causes premature flowering and overrides the $\mathrm{CR}$ for dormancy release
(Srinivasan et al., 2012). Similar phenotypes were observed in apple trees overexpressing MdoFT1 (Tränkner et al., 2010), an apple FT-like gene that is found within a QTL related to budbreak date (Allard et al., 2016). In all these species, it is likely that FT-like genes antagonize the function of some DAM and SVP-like genes. Because SVP inhibits FT mRNA expression in Arabidopsis, it could be possible that DAM and SVP-like proteins act as transcription repressors of FT-like genes in perennial species (Figure 4). In agreement with this hypothesis, Hao et al. (2015) showed by chromatin immunoprecipitation followed by qPCR (ChIP-qPCR) that DAM proteins bind to CArG boxes located in the promoter regions of leafy spurge FT genes during endodormancy. Similarly, in vitro experiments evidenced that the Japanese pear PpyDAM1 inhibits the expression of PpyFT2 by binding to its promoter (Niu et al., 2016). Consistently, PpyFT2 expression levels are opposite to those observed for PpyDAMs, remaining low during dormancy and increasing after dormancy release (Ito et al., 2016; Niu et al., 2016). A comparable pattern of expression was reported in apple, in which the expression levels of MdoFT1 and MdoFT2 are down-regulated during the winter, and MdoFT2 is highly upregulated after dormancy release (Kotoda et al., 2010). In hybrid aspen, SVL directly repressed the mRNA expression of FT1 and ChIP-qPCR experiments showed that Myc-SVL binds to a CArG box on the FT1 promoter (Singh et al., 2018). Controversially, other studies do not support the direct regulation of FT-like genes by DAM and SVP-like transcription factors. Indeed, FT-like genes were not found as direct targets of AchSVP2 (Wu et al., 2017c) and PpyMADS13-1 (Saito et al., 2015) in ChIP-seq and transient reporter assays, respectively. However, whether technical issues masked the interaction of the transcription factors with FT-like loci, or whether the absence of binding is biologically meaningful requires further studies.

\section{DAM, SVP-Like Genes and Plant Hormones}

The involvement of plant hormones in the control of dormancy cycle has been suggested and reviewed in Powell (1987) and Cooke et al. (2012). In particular, it has been suggested that ABA is a growth-inhibiting hormone (Wareing, 1978) that plays a significant role as a regulator of dormancy in seeds (Wareing, 1978; Kermode, 2005; Finkelstein, 2013), and in the bud dormancy cycle (Chmielewski et al., 2017; Tuan et al., 2017; Yue et al., 2017; Tylewicz et al., 2018). This idea is mainly supported by the observation that, in many tree species, ABA content (directly measured or indirectly inferred by gene expression studies) increases within the bud after growth cessation correlating with dormancy induction (Rinne et al., 1994; Karlberg et al., 2010; Chmielewski et al., 2017). However, the above-mentioned studies did not provide genetic evidence on the role of $\mathrm{ABA}$ in bud dormancy control. In Populus species, an elegant model for ABA-mediated regulation of dormancy in response to photoperiod has been recently proposed (Tylewicz et al., 2018). Short photoperiods induce the accumulation of $\mathrm{ABA}$ as well as the expression of genes related to ABA biosynthesis (ABA DEFICIENT 1 [ABA1], ABA2, and 9-cis-epoxycarotenoid dioxygenase $[N C E D]$ ) and signaling 
(PROTEIN PHOSPHATASE 2C [PP2C] and ABA-RESPONSIVE ELEMENT BINDING PROTEIN [AREB/ABF]) (Rohde et al., 2002; Ruttink et al., 2007; Karlberg et al., 2010). In turn, the accumulation of $\mathrm{ABA}$ in the buds triggers the plasmodesmata closure, which ensures the growth arrest and bud dormancy until sufficient chilling is accumulated (Tylewicz et al., 2018). Expression of the dominant negative abi1-1 allele of ABSCISIC ACID-INSENSITIVE3 (ABI3) in transgenic poplar trees led to reduced $A B A$ responses. These transgenic trees failed to induce plasmodesmata closure at dormancy onset and display a shorter dormancy cycle compare to wild-types (Tylewicz et al., 2018). Thus, the accumulation of high ABA levels in the buds seems to be crucial for dormancy regulation.

In temperate fruit trees, $D A M$ and $S V P$-like genes likely participate in the control of ABA homeostasis (Figure 4). For example, SVL was suggested to inhibit budbreak in hybrid aspen at least partially by the transcriptional activation of genes encoding NCED3 and ABA receptors (Singh et al., 2018). Similar to the model proposed for poplar, in temperate fruit trees ABA levels are high in dormant buds and decrease during the transition from endo to ecodormancy (Chmielewski et al., 2017). This kinetics of ABA accumulation is related to the activity of NCEDs genes in Japanese pear and peach (Wang et al., 2015; Tuan et al., 2017). In Japanese pear, PPyNCED 3 increased toward endodormancy release in lateral flower buds of 'Kosui' pear (Tuan et al., 2017). By making use of transient assays with dual luciferase reporter system (LUC assay) and electrophoretic mobility shift assay (EMSA), Tuan et al. (2017) reported that $P p y D A M 1$ activates the transcription of $P p y N C E D 3$ by binding to a CArG box located in the PPyNCED3 promoter (Tuan et al., 2017). Therefore, PpyDAM1 would positively regulate the accumulation of ABA during the endodormancy. Interestingly, high levels of ABA could promote the downregulation of PpyDAM1 during endodormancy release, as a part of a feedback regulatory system (Figure 4) (Tuan et al., 2017). The idea that DAM and SVP-like transcription factors could act in the dormancy cycle through the regulation of $\mathrm{ABA}$ homeostasis and signaling was also suggested in other species. For example, the overexpression of the kiwifruit AdeSVP2 gene may have mimicked the effect of $\mathrm{ABA}$ on the plant dehydration response during bud dormancy (Wu et al., 2017b). Indeed, a ChIP-seq experiment showed that the kiwifruit AchSVP2 is able to bind several genes related to $\mathrm{ABA}$, dehydration and osmotic response. However, the AchSVP2 protein did not bind to kiwifruit NCED homologs as shown for PpyDAM1 in Japanese pear, and how AchSVP2 would regulate ABA-related responses remains unclear. This suggests the existence of divergent evolutionary mechanisms of ABA regulation of bud dormancy mediated by DAM and SVP-proteins (Wu et al., 2017c).

It is worthy to mention here that, besides $\mathrm{ABA}$, other plant hormones (e.g., GA, cytokinins) are likely involved in the regulation of bud dormancy cycle (see reviews: Tamaki et al., 2007; Cooke et al., 2012; Horvath et al., 2003). Among them, GA could play a role in dormancy release and budbreak (Rinne et al., 2011; Singh et al., 2018), and its biosynthetic pathway was shown to be controlled by SVP-like encoding genes. In Arabidopsis, SVP prevented the accumulation of GA in the SAM during the floral transition by repressing the expression of GIBBERELLIN 20 OXIDASE 2 (GA20ox2), a gene encoding an enzyme required for biosynthesis of GA (Andrés et al., 2014). Similarly, SVL repressed the expression of GA20ox genes in hybrid aspen (Singh et al., 2018), suggesting a role of $S V P$-like genes in controlling budbreak. However, whether DAM and SVP-like genes act on dormancy cycle in fruit tree species by controlling GA levels has not been studied yet.

\section{Transcriptional Complexes Could Be Involved in Bud Dormancy Control}

MADS-box transcription factors form multimeric complexes to regulate floral organ identity (Schwarz-Sommer et al., 1990; EgeaCortines et al., 1999; Honma and Goto, 2001). The combination of different MADS-box proteins in transcriptional complexes define their function by conferring target specificity. Thus, the same MADS-box protein could have different roles depending on the composition of the complex. Arabidopsis SVP forms complexes with several other MADS-box proteins to regulate floral development and flowering time (de Folter et al., 2005; Gregis et al., 2006; Lee et al., 2007; Balanzà et al., 2014; Mateos et al., 2015). SVP also interacts with FLC to form a complex that inhibits flowering, partially by repression of the floral integrator genes FT and SOC1 (Lee et al., 2007) as well as GA-related genes (Andrés et al., 2014; Mateos et al., 2015). A gene similar to FLC (FLC-like) has been identified in two independent transcriptomic studies as a putative regulator of apple bud dormancy (Porto et al., 2015; Kumar et al., 2016). However, whether FLC-like proteins form part of a transcriptional complex with DAM and SVP-like to control bud dormancy remains totally unknown. Other protein complexes between DAM and SVP-like and other MADS-box proteins have been recently reported. In Japanese apricot, yeast-twohybrid $(\mathrm{Y} 2 \mathrm{H})$ and bimolecular complementation assays (BiFC) showed that PmuDAM1, PmuDAM5, and PmuDAM6 could form combinatorial proteins complexes (Zhao et al., 2018b). According to their pattern of expression, the authors argued that these complexes could act during different phases of the dormancy cycle, although these phases were not clearly determined in this study. In addition, an $\mathrm{Y} 2 \mathrm{H}$ screening identified an interaction between PmuDAM6 and PmuSOC1 (Kitamura et al., 2016).

The above-mentioned examples illustrate the existence of DAM and SVP-like-containing transcriptional complexes in fruit trees. The composition of these complexes might encrypt particular functions during the dormancy cycle. Thus, unraveling the nature of these complexes, as it was already done in Arabidopsis (de Folter et al., 2005), will help to better understand the function of DAM and SVP-like proteins.

\section{FINAL REMARKS AND PERSPECTIVES}

There is a significant correlation between the expression profile of $D A M$ and $S V P$-like genes and the progression of the dormancy cycle. In addition, the ectopic expression of DAM and SVPlike genes from strong constitutive promoters (i.e., the $35 \mathrm{~S}$ 
promoter) affected the patterns of dormancy and flowering in a diverse number of perennial plant species. All the studies summarized in this review have enormously contributed to progressively decipher the functions of DAM and SVP-like genes in temperate fruit tree species. However, with the exception of the evg peach mutant and the functional characterization of $S V L$ in hybrid aspen, definitive arguments supporting the individual and collective (as part of transcriptional complexes) function of the distinct DAM and SVP-like genes in dormancy cycle control of these species are still missing. In the era of the genome editing technology, a systematic survey of fruit tree knockout and knockdown mutants are expected to unambiguously characterize their function. In addition, the use of genome-wide technologies as for example ChIP-seq will shed light on the molecular function of this interesting group of genes.

\section{REFERENCES}

Akhtar, M., Jaiswal, A., Taj, G., Jaiswal, J. P., Qureshi, M. I., and Singh, N. K. (2012). DREB1/CBF transcription factors: their structure, function and role in abiotic stress tolerance in plants. J. Genet. 91, 385-395. doi: 10.1007/s12041-012-0201-3

Allard, A., Bink, M. C., Martinez, S., Kelner, J.-J., Legave, J.-M., di Guardo, M., et al. (2016). Detecting QTLs and putative candidate genes involved in budbreak and flowering time in an apple multiparental population. J. Exp. Bot. 67, 2875-2888. doi: $10.1093 /$ jxb/erw130

Anderson, J. V. (2015). Advances in Plant Dormancy. Berlin: Springer. doi: 10.1007/ 978-3-319-14451-1

Andrés, F., and Coupland, G. (2012). The genetic basis of flowering responses to seasonal cues. Nat. Rev. Genet. 13, 627-639. doi: 10.1038/nrg3291

Andrés, F., Porri, A., Torti, S., Mateos, J., Romera-Branchat, M., García-Martínez, J. L., et al. (2014). Short vegetative phase reduces gibberellin biosynthesis at the Arabidopsis shoot apex to regulate the floral transition. Proc. Natl. Acad. Sci. U.S.A. 111, E2760-E2769. doi: 10.1073/pnas.1409567111

Bai, S., Saito, T., Sakamoto, D., Ito, A., Fujii, H., and Moriguchi, T. (2013). Transcriptome analysis of Japanese pear (Pyrus pyrifolia Nakai) flower buds transitioning through endodormancy. Plant Cell Physiol. 54, 1132-1151. doi: $10.1093 / \mathrm{pcp} / \mathrm{pct} 067$

Balanzà, V., Martínez-Fernández, I., and Ferrándiz, C. (2014). Sequential action of FRUITFULL as a modulator of the activity of the floral regulators SVP and SOC1. J. Exp. Bot. 65, 1193-1203. doi: 10.1093/jxb/ert482

Bastow, R., Mylne, J. S., Lister, C., Lippman, Z., Martienssen, R. A., and Dean, C. (2004). Vernalization requires epigenetic silencing of FLC by histone methylation. Nature 427, 164-167. doi: 10.1038/nature02269

Beauvieux, R., Wenden, B., and Dirlewanger, E. (2018). Bud dormancy in perennial fruit tree species: a pivotal role for oxidative cues. Front. Plant Sci. 9:657. doi: $10.3389 /$ fpls.2018.00657

Bielenberg, D. G., Rauh, B., Fan, S., Gasic, K., Abbott, A. G., Reighard, G. L., et al. (2015). Genotyping by sequencing for SNP-based linkage map construction and QTL analysis of chilling requirement and bloom date in peach [Prunus persica (L.) Batsch]. PLoS One 10:e0139406. doi: 10.1371/journal.pone. 0139406

Bielenberg, D. G., Wang, Y., Li, Z., Zhebentyayeva, T., Fan, S., Reighard, G. L., et al. (2008). Sequencing and annotation of the evergrowing locus in peach [Prunus persica (L.) Batsch] reveals a cluster of six MADS-box transcription factors as candidate genes for regulation of terminal bud formation. Tree Genet. Genomes 4, 495-507. doi: 10.1007/s11295-007-0126-9

Böhlenius, H., Huang, T., Charbonnel-Campaa, L., Brunner, A. M., Jansson, S., Strauss, S. H., et al. (2006). CO/FT regulatory module controls timing of flowering and seasonal growth cessation in trees. Science 312, 1040-1043. doi: 10.1126/science.1126038

Campoy, J. A., Ruiz, D., and Egea, J. (2011). Dormancy in temperate fruit trees in a global warming context: a review. Sci. Hortic. 130, 357-372. doi: 10.1016/j. scienta.2011.07.011

\section{AUTHOR CONTRIBUTIONS}

VF, EC, and FA contributed to the conception and the writing of the manuscript. BG performed the phylogenetic analysis. All authors contributed to manuscript revision, read and approved the submitted version.

\section{FUNDING}

This work was supported by Agropolis Fondation under the reference ID 1503-008 through the "Investissements d'Avenir» program (Labex Agro: ANR-10-LABX-0001-01). VF received a grant from the AgreenSkills+ EU fellowship program (FP7609398).

Castède, S., Campoy, J. A., Le Dantec, L., Quero-García, J., Barreneche, T., Wenden, B., et al. (2015). Mapping of candidate genes involved in bud dormancy and flowering time in sweet cherry (Prunus avium). PLoS One 10:e0143250. doi: 10.1371/journal.pone.0143250

Castresana, J. (2000). Selection of conserved blocks from multiple alignments for their use in phylogenetic analysis. Mol. Biol. Evol. 17, 540-552. doi: 10.1093/ oxfordjournals.molbev.a026334

Celton, J.-M., Martinez, S., Jammes, M.-J., Bechti, A., Salvi, S., Legave, J.-M., et al. (2011). Deciphering the genetic determinism of bud phenology in apple progenies: a new insight into chilling and heat requirement effects on flowering dates and positional candidate genes. New Phytol. 192, 378-392. doi: 10.1111/j. 1469-8137.2011.03823.x

Champagnat, P. (1989). Rest and activity in vegetative buds of trees. Ann. For. Sci. 46, 9s-26s. doi: 10.1051/forest:19890501

Chmielewski, F., Gotz, K., Homann, T., Huschek, G., and Rawel, H. (2017). Identification of endodormancy release for cherries (Prunus avium L.) by abscisic acid and sugars. J. Hortic. 4:210. doi: 10.4172/2376-0354.1000210

Conde, D., Le Gac, A. L., Perales, M., Dervinis, C., Kirst, M., Maury, S., et al. (2017a). Chilling-responsive DEMETER-LIKE DNA demethylase mediates in poplar bud break. Plant Cell Environ. 40, 2236-2249. doi: 10.1111/pce.13019

Conde, D., Moreno-Cortés, A., Dervinis, C., Ramos-Sánchez, J. M., Kirst, M., Perales, M., et al. (2017b). Overexpression of DEMETER, a DNA demethylase, promotes early apical bud maturation in poplar. Plant Cell Environ. 40, 28062819. doi: 10.1111/pce.13056

Considine, M. J., and Foyer, C. H. (2014). Redox regulation of plant development. Antioxid. Redox Signal. 21, 1305-1326. doi: 10.1089/ars.2013.5665

Cook, N. C., and Jacobs, G. (1999). Suboptimal winter chilling impedes development of acrotony in apple shoots. Hortscience 34, 1213-1216.

Cooke, J. E., Eriksson, M. E., and Junttila, O. (2012). The dynamic nature of bud dormancy in trees: environmental control and molecular mechanisms. Plant Cell Environ. 35, 1707-1728. doi: 10.1111/j.1365-3040.2012.02552.x

Corbeer, L., Vincent, C., Jang, S., Fornara, F., Fan, Q., Searle, I., et al. (2007). FT protein movement contributes to long-distance signaling in floral induction of Arabidopsis. Science 316, 1030-1033. doi: 10.1126/science.1141752

Crabbe, J. C., and Barnola, P. (1996). "A new conceptual approach to bud dormancy in woody plants," in Plant Dormancy: Physiology, Biochemistry and Molecular Biology, ed. G. A. Lang (London: CAB International), 83-113.

de Folter, S., Immink, R. G., Kieffer, M., Paøenicová, L., Henz, S. R., Weigel, D., et al. (2005). Comprehensive interaction map of the Arabidopsis MADS Box transcription factors. Plant Cell 17, 1424-1433. doi: 10.1105/tpc.105.031831

de la Fuente, L., Conesa, A., Lloret, A., Badenes, M. L., and Ríos, G. (2015). Genome-wide changes in histone $\mathrm{H} 3$ lysine 27 trimethylation associated with bud dormancy release in peach. Tree Genet. Genomes 11:45. doi: 10.1007/ s11295-015-0869-7

Doğramaci, M., Horvath, D. P., Chao, W. S., Foley, M. E., Christoffers, M. J., and Anderson, J. V. (2010). Low temperatures impact dormancy status, flowering competence, and transcript profiles in crown buds of leafy spurge. Plant Mol. Biol. 73, 207-226. doi: 10.1007/s11103-010-9621-8 
Egea-Cortines, M., Saedler, H., and Sommer, H. (1999). Ternary complex formation between the MADS-box proteins SQUAMOSA, DEFICIENS and GLOBOSA is involved in the control of floral architecture in Antirrhinum majus. EMBO J. 18, 5370-5379. doi: 10.1093/emboj/18.19.5370

Falavigna, V. S., Porto, D. D., Buffon, V., Margis-Pinheiro, M., Pasquali, G., and Revers, L. F. (2014). Differential transcriptional profiles of dormancy-related genes in apple buds. Plant Mol. Biol. Rep. 32, 796-813. doi: 10.1007/s11105013-0690-0

Falavigna, V. S., Porto, D. D., Silveira, C. P., and Revers, L. F. (2015). "Recent advances in genetics and molecular control of bud dormancy in pipfruits," in Advances in Plant Dormancy, ed. J. V. Anderson (Cham: Springer International Publishing), 107-122.

Fan, S., Bielenberg, D. G., Zhebentyayeva, T. N., Reighard, G. L., Okie, W. R., Holland, D., et al. (2010). Mapping quantitative trait loci associated with chilling requirement, heat requirement and bloom date in peach (Prunus persica). New Phytol. 185, 917-930. doi: 10.1111/j.1469-8137.2009.03 119.x

Finkelstein, R. (2013). Abscisic acid synthesis and response. Arabidopsis Book 11:e0166. doi: 10.1199/tab.0166

Gabay, G., Dahan, Y., Izhaki, Y., Isaacson, T., Elkind, Y., Ben-Ari, G., et al. (2017). Identification of QTLs associated with spring vegetative budbreak time after dormancy release in pear (Pyrus communis L.). Plant Breed. 136, 749-758. doi: $10.1111 /$ pbr.12499

Gazzani, S., Gendall, A. R., Lister, C., and Dean, C. (2003). Analysis of the molecular basis of flowering time variation in Arabidopsis accessions. Plant Physiol. 132, 1107-1114. doi: 10.1104/pp.103.021212

Gregis, V., Andrés, F., Sessa, A., Guerra, R. F., Simonini, S., Mateos, J. L., et al. (2013). Identification of pathways directly regulated by SHORT VEGETATIVE PHASE during vegetative and reproductive development in Arabidopsis. Genome Biol. 14:R56. doi: 10.1186/gb-2013-14-6-r56

Gregis, V., Sessa, A., Colombo, L., and Kater, M. M. (2006). AGL24, SHORT VEGETATIVE PHASE, and APETALA1 redundantly control AGAMOUS during early stages of flower development in Arabidopsis. Plant Cell 18, 1373-1382. doi: 10.1105/tpc.106.041798

Guindon, S., and Gascuel, O. (2003). A simple, fast, and accurate algorithm to estimate large phylogenies by maximum likelihood. Syst. Biol. 52, 696-704. doi: 10.1080/10635150390235520

Guo, L., Dai, J., Ranjitkar, S., Yu, H., Xu, J., and Luedeling, E. (2014). Chilling and heat requirements for flowering in temperate fruit trees. Int. J. Biometeorol. 58, 1195-1206. doi: 10.1007/s00484-013-0714-3

Guo, L., Dai, J., Wang, M., Xu, J., and Luedeling, E. (2015). Responses of spring phenology in temperate zone trees to climate warming: a case study of apricot flowering in China. Agric. For. Meteorol. 201, 1-7. doi: 10.1016/j.agrformet. 2014.10.016

Guo, X., Ma, Z., Zhang, Z., Cheng, L., Zhang, X., and Li, T. (2017). Small RNA-sequencing links physiological changes and RdDM process to vegetativeto-floral transition in apple. Front. Plant Sci. 8:873. doi: 10.3389/fpls.2017. 00873

Habu, T., Yamane, H., Igarashi, K., Hamada, K., Yano, K., and Tao, R. (2012). 454Pyrosequencing of the transcriptome in leaf and flower buds of Japanese apricot (Prunus mume Sieb. et Zucc.) at different dormant stages. J. Jpn. Soc. Hortic. Sci. 81, 239-250. doi: 10.2503/jjshs1.81.239

Habu, T., Yamane, H., Sasaki, R., Yano, K., Fujii, H., Shimizu, T., et al. (2014). Custom microarray analysis for transcript profiling of dormant vegetative buds of Japanese apricot during prolonged chilling exposure. J. Jpn. Soc. Hortic. Sci. 83, 1-16. doi: 10.2503/jjshs1.CH-077

Hao, X., Chao, W., Yang, Y., and Horvath, D. (2015). Coordinated expression of FLOWERING LOCUS T and DORMANCY ASSOCIATED MADS-BOXlike genes in leafy spurge. PLoS One 10:e0126030. doi: 10.1371/journal.pone. 0126030

Hao, X., Yang, Y., Yue, C., Wang, L., Horvath, D. P., and Wang, X. (2017). Comprehensive transcriptome analyses reveal differential gene expression profiles of Camellia sinensis axillary buds at para-, endo-, ecodormancy, and Bud flush stages. Front. Plant Sci. 8:553. doi: 10.3389/fpls.2017.00553

Hartmann, U., Höhmann, S., Nettesheim, K., Wisman, E., Saedler, H., and Huijser, P. (2000). Molecular cloning of SVP: a negative regulator of the floral transition in Arabidopsis. Plant J. 21, 351-360. doi: 10.1046/j.1365-313x.2000. 00682.x
He, Y., Doyle, M. R., and Amasino, R. (2004). PAF1-complex-mediated histone methylation of FLOWERING LOCUS C chromatin is required for the vernalization-responsive, winter-annual habit in Arabidopsis. Genes Dev. 18, 2774-2784. doi: 10.1101/gad.1244504

Heide, O. M., and Prestrud, A. K. (2005). Low temperature, but not photoperiod, controls growth cessation and dormancy induction and release in apple and pear. Tree Physiol. 25, 109-114. doi: 10.1093/treephys/25.1.109

Heo, J. B., and Sung, S. (2011). Vernalization-mediated epigenetic silencing by a long intronic noncoding RNA. Science 331, 76-79. doi: 10.1126/science. 1197349

Hong, R. L. (2003). Regulatory elements of the floral homeotic gene AGAMOUS identified by phylogenetic footprinting and shadowing. Plant Cell Online 15, 1296-1309. doi: 10.1105/tpc.009548

Honma, T., and Goto, K. (2001). Complexes of MADS-box proteins are sufficient to convert leaves into floral organs. Nature 409, 525-529. doi: 10.1038/35054083

Horvath, D. (2009). Common mechanisms regulate flowering and dormancy. Plant Sci. 177, 523-531. doi: 10.1016/j.plantsci.2009.09.002

Horvath, D. P., Anderson, J. V., Chao, W. S., and Foley, M. E. (2003). Knowing when to grow: signals regulating bud dormancy. Trends Plant Sci. 8, 534-540. doi: 10.1016/j.tplants.2003.09.013

Horvath, D. P., Chao, W. S., Suttle, J. C., Thimmapuram, J., and Anderson, J. V. (2008). Transcriptome analysis identifies novel responses and potential regulatory genes involved in seasonal dormancy transitions of leafy spurge (Euphorbia esula L.). BMC Genomics 9:536. doi: 10.1186/1471-2164-9-536

Horvath, D. P., Kudrna, D., Talag, J., Anderson, J. V., Chao, W. S., Wing, R., et al. (2013). BAC library development and clone characterization for dormancyresponsive DREB4A,DAM, and FT from Leafy spurge (Euphorbia esula) identifies differential splicing and conserved promoter motifs. Weed Sci. 61, 303-309. doi: 10.1614/WS-D-12-00175.1

Horvath, D. P., Sung, S., Kim, D., Chao, W., and Anderson, J. (2010). Characterization, expression and function of DORMANCY ASSOCIATED MADS-BOX genes from leafy spurge. Plant Mol. Biol. 73, 169-179. doi: 10.1007/ s11103-009-9596-5

Howe, G. T., Horvath, D. P., Dharmawardhana, P., Priest, H. D., Mockler, T. C., and Strauss, S. H. (2015). Extensive transcriptome changes during natural onset and release of vegetative bud dormancy in Populus. Front. Plant Sci. 6:989. doi: 10.3389/fpls.2015.00989

Hsu, C.-Y., Adams, J. P., Kim, H., No, K., Ma, C., Strauss, S. H., et al. (2011). FLOWERING LOCUS T duplication coordinates reproductive and vegetative growth in perennial poplar. Proc. Natl. Acad. Sci. U.S.A. 108, 10756-10761. doi: 10.1073/pnas.1104713108

Ito, A., Saito, T., Sakamoto, D., Sugiura, T., Bai, S., and Moriguchi, T. (2016). Physiological differences between bud breaking and flowering after dormancy completion revealed by DAM and FT/TFL1 expression in Japanese pear (Pyrus pyrifolia). Tree Physiol. 36, 109-120. doi: 10.1093/treephys/tpv115

Jaeger, K. E., and Wigge, P. A. (2007). FT protein acts as a long-range signal in Arabidopsis. Curr. Biol. 17, 1050-1054. doi: 10.1016/j.cub.2007.05.008

Jang, S., Torti, S., and Coupland, G. (2009). Genetic and spatial interactions between FT, TSF and SVP during the early stages of floral induction in Arabidopsis. Plant J. 60, 614-625. doi: 10.1111/j.1365-313X.2009. 03986.x

Jiménez, S., Lawton-Rauh, A. L., Reighard, G. L., Abbott, A. G., and Bielenberg, D. G. (2009). Phylogenetic analysis and molecular evolution of the dormancy associated MADS-box genes from peach. BMC Plant Biol. 9:81. doi: 10.1186/ 1471-2229-9-81

Jiménez, S., Li, Z., Reighard, G. L., and Bielenberg, D. G. (2010a). Identification of genes associated with growth cessation and bud dormancy entrance using a dormancy-incapable tree mutant. BMC Plant Biol. 10:25. doi: 10.1186/14712229-10-25

Jiménez, S., Reighard, G. L., and Bielenberg, D. G. (2010b). Gene expression of DAM5 and DAM6 is suppressed by chilling temperatures and inversely correlated with bud break rate. Plant Mol. Biol. 73, 157-167. doi: 10.1007/ s11103-010-9608-5

Kardailsky, I., Shukla, V. K., Ahn, J. H., Dagenais, N., Christensen, S. K., Nguyen, J. T., et al. (1999). Activation tagging of the floral inducer FT. Science 286, 1962-1965. doi: 10.1126/science.286.5446.1962

Karlberg, A., Englund, M., Petterle, A., Molnar, G., Sjödin, A., Bako, L., et al. (2010). Analysis of global changes in gene expression during activity-dormancy cycle in 
hybrid aspen apex. Plant Biotechnol. 27, 1-16. doi: 10.5511/plantbiotechnology. 27.1

Katoh, K., Misawa, K., Kuma, K., and Miyata, T. (2002). MAFFT: a novel method for rapid multiple sequence alignment based on fast Fourier transform. Nucleic Acids Res. 30, 3059-3066. doi: 10.1093/nar/gkf436

Kaufmann, K., Melzer, R., and Theißen, G. (2005). MIKC-type MADS-domain proteins: structural modularity, protein interactions and network evolution in land plants. Gene 347, 183-198. doi: 10.1016/j.gene.2004.12.014

Kermode, A. R. (2005). Role of abscisic acid in seed dormancy. J. Plant Growth Regul. 24, 319-344. doi: 10.1007/s00344-005-0110-2

Kitamura, Y., Habu, T., Yamane, H., Nishiyama, S., Kajita, K., Sobue, T., et al. (2018). Identification of QTLs controlling chilling and heat requirements for dormancy release and bud break in Japanese apricot (Prunus mume). Tree Genet. Genomes 14:33. doi: 10.1007/s11295-018-1243-3

Kitamura, Y., Takeuchi, T., Yamane, H., and Tao, R. (2016). Simultaneous down-regulation of DORMANCY-ASSOCIATED MADS-box6 and SOC1 during dormancy release in Japanese apricot (Prunus mume) flower buds. J. Hortic. Sci. Biotechnol. 91, 476-482. doi: 10.1080/14620316.2016.117 3524

Kobayashi, Y., Kaya, H., Goto, K., Iwabuchi, M., and Araki, T. (1999). A pair of related genes with antagonistic roles in mediating flowering signals. Science 286, 1960-1962. doi: 10.1126/science.286.5446.1960

Kotoda, N., Hayashi, H., Suzuki, M., Igarashi, M., Hatsuyama, Y., Kidou, S.I., et al. (2010). Molecular characterization of FLOWERING LOCUS T-like genes of apple (Malus x domestica Borkh.). Plant Cell Physiol. 51, 561-575. doi: $10.1093 / \mathrm{pcp} / \mathrm{pcq} 021$

Kramer, P. J. (1936). Effect of variation in length of day on growth and dormancy of trees. Plant Physiol. 11, 127-137. doi: 10.1104/pp.11.1.127

Kumar, G., Arya, P., Gupta, K., Randhawa, V., Acharya, V., and Singh, A. K. (2016). Comparative phylogenetic analysis and transcriptional profiling of MADS-box gene family identified DAM and FLC-like genes in apple (Malus x domestica). Sci. Rep. 6:20695. doi: 10.1038/srep20695

Kumar, G., Gupta, K., Pathania, S., Swarnkar, M. K., Rattan, U. K., Singh, G., et al. (2017). Chilling affects phytohormone and post-embryonic development pathways during bud break and fruit set in apple (Malus domestica Borkh.). Sci. Rep. 7:42593. doi: 10.1038/srep42593

Kumar, S. V., and Wigge, P. A. (2010). H2A.Z-containing nucleosomes mediate the thermosensory response in Arabidopsis. Cell 140, 136-147. doi: 10.1016/j.cell. 2009.11.006

Lang, G. A., Early, J. D., Martin, G. C., and Darnell, R. L. (1987). Endo-, para-, and ecodormancy: physiological terminology and classification for dormancy research. Hortscience 22, 371-377.

Lee, J. H., Yoo, S. J., Park, S. H., Hwang, I., Lee, J. S., and Ahn, J. H. (2007). Role of SVP in the control of flowering time by ambient temperature in Arabidopsis. Genes Dev. 21, 397-402. doi: 10.1101/gad.1518407

Legave, J. M., Blanke, M., Christen, D., Giovannini, D., Mathieu, V., and Oger, R. (2013). A comprehensive overview of the spatial and temporal variability of apple bud dormancy release and blooming phenology in Western Europe. Int. J. Biometeorol. 57, 317-331. doi: 10.1007/s00484-012-0551-9

Legave, J.-M., Guédon, Y., Malagi, G., El Yaacoubi, A., and Bonhomme, M. (2015). Differentiated responses of apple tree floral phenology to global warming in contrasting climatic regions. Front. Plant Sci. 6:1054. doi: 10.3389/fpls.2015. 01054

Leida, C., Conesa, A., Llácer, G., Badenes, M. L., and Ríos, G. (2012). Histone modifications and expression of DAM6 gene in peach are modulated during bud dormancy release in a cultivar-dependent manner. New Phytol. 193, 67-80. doi: 10.1111/j.1469-8137.2011.03863.x

Leida, C., Terol, J., Martí, G., Agustí, M., Llácer, G., Badenes, M. L., et al. (2010). Identification of genes associated with bud dormancy release in Prunus persica by suppression subtractive hybridization. Tree Physiol. 30, 655-666. doi: 10.1093/treephys/tpq008

Li, D., Liu, C., Shen, L., Wu, Y., Chen, H., Robertson, M., et al. (2008). A repressor complex governs the integration of flowering signals in Arabidopsis. Dev. Cell 15, 110-120. doi: 10.1016/j.devcel.2008.05.002

Li, Y., Fang, W. C., Zhu, G. R., Cao, K., Chen, C. W., Wang, X. W., et al. (2016). Accumulated chilling hours during endodormancy impact blooming and fruit shape development in peach (Prunus persica L.). J. Integr. Agric. 15, 1267-1274. doi: 10.1016/S2095-3119(16)61374-6
Li, Y., Zhou, Y., Yang, W., Cheng, T., Wang, J., and Zhang, Q. (2017). Isolation and functional characterization of SVP-like genes in Prunus mume. Scientia Horticulturae 215, 91-101. doi: 10.1016/j.scienta.2016.12.013

Li, Z., Reighard, G. L., Abbott, A. G., and Bielenberg, D. G. (2009). Dormancyassociated MADS genes from the EVG locus of peach [Prunus persica (L.) Batsch] have distinct seasonal and photoperiodic expression patterns. J. Exp. Bot. 60, 3521-3530. doi: 10.1093/jxb/erp195

Liu, G., Li, W., Zheng, P., Xu, T., Chen, L., Liu, D., et al. (2012). Transcriptomic analysis of "Suli" pear (Pyrus pyrifolia white pear group) buds during the dormancy by RNA-Seq. BMC Genomics 13:700. doi: 10.1186/1471-2164-13-700

Liu, J., He, Y., Amasino, R., and Chen, X. (2004). siRNAs targeting an intronic transposon in the regulation of natural flowering behavior in Arabidopsis. Genes Dev. 18, 2873-2878. doi: 10.1101/gad.1217304

Luedeling, E., Girvetz, E. H., Semenov, M. A., and Brown, P. H. (2011). Climate change affects winter chill for temperate fruit and nut trees. PLoS One 6:e20155. doi: 10.1371/journal.pone.0020155

Lutz, U., Posé, D., Pfeifer, M., Gundlach, H., Hagmann, J., Wang, C., et al. (2015). Modulation of ambient temperature-dependent flowering in Arabidopsis thaliana by natural variation of FLOWERING LOCUS M. PLoS Genet. 11:e1005588. doi: 10.1371/journal.pgen.1005588

Mateos, J. L., Madrigal, P., Tsuda, K., Rawat, V., Richter, R., Romera-Branchat, M., et al. (2015). Combinatorial activities of SHORT VEGETATIVE PHASE and FLOWERING LOCUS C define distinct modes of flowering regulation in Arabidopsis. Genome Biol. 16:31. doi: 10.1186/s13059-015-0597-1

Mathieu, J., Warthmann, N., Küttner, F., and Schmid, M. (2007). Export of FT protein from phloem companion cells is sufficient for floral induction in Arabidopsis. Curr. Biol. 17, 1055-1060. doi: 10.1016/j.cub.2007.05.009

Maurya, J. P., and Bhalerao, R. P. (2017). Photoperiod- and temperature-mediated control of growth cessation and dormancy in trees: a molecular perspective. Ann. Bot. 120, 351-360. doi: 10.1093/aob/mcx061

Mazzitelli, L., Hancock, R. D., Haupt, S., Walker, P. G., Pont, S. D., McNicol, J., et al. (2007). Co-ordinated gene expression during phases of dormancy release in raspberry (Rubus idaeus L.) buds. J. Exp. Bot. 58, 1035-1045. doi: 10.1093/ jxb/erl266

Meitha, K., Agudelo-Romero, P., Signorelli, S., Gibbs, D. J., Considine, J. A., Foyer, C. H., et al. (2018). Developmental control of hypoxia during bud burst in grapevine. Plant Cell Environ. 41, 1154-1170. doi: 10.1111/pce.13141

Meitha, K., Konnerup, D., Colmer, T. D., Considine, J. A., Foyer, C. H., and Considine, M. J. (2015). Spatio-temporal relief from hypoxia and production of reactive oxygen species during bud burst in grapevine (Vitis vinifera). Ann. Bot. 116, 703-711. doi: 10.1093/aob/mcv123

Michaels, S. D., and Amasino, R. M. (1999). FLOWERING LOCUS C encodes a novel mads domain protein that acts as a repressor of flowering. Plant Cell 11, 949-956. doi: 10.1105/tpc.11.5.949

Michaels, S. D., Ditta, G., Gustafson-Brown, C., Pelaz, S., Yanofsky, M., and Amasino, R. M. (2003). AGL24 acts as a promoter of flowering in Arabidopsis and is positively regulated by vernalization. Plant J. 33, 867-874. doi: 10.1046/j. 1365-313X.2003.01671.x

Mikkelsen, M. D., and Thomashow, M. F. (2009). A role for circadian evening elements in cold-regulated gene expression in Arabidopsis. Plant J. 60, 328-339. doi: 10.1111/j.1365-313X.2009.03957.x

Mimida, N., Saito, T., Moriguchi, T., Suzuki, A., Komori, S., and Wada, M. (2015). Expression of DORMANCY-ASSOCIATED MADS-BOX (DAM)-like genes in apple. Biol. Plant. 59, 237-244. doi: 10.1007/s10535-015-0503-4

Niu, Q., Li, J., Cai, D., Qian, M., Jia, H., Bai, S., et al. (2016). Dormancy-associated MADS-box genes and microRNAs jointly control dormancy transition in pear (Pyrus pyrifolia white pear group) flower bud. J. Exp. Bot. 67, 239-257. doi: $10.1093 /$ jxb/erv454

Olukolu, B. A., Trainin, T., Fan, S., Kole, C., Bielenberg, D. G., Reighard, G. L., et al. (2009). Genetic linkage mapping for molecular dissection of chilling requirement and budbreak in apricot (Prunus armeniaca L.). Genome 52, 819-828. doi: 10.1139/G09-050

Paul, L. K., Rinne, P. L., and Van der Schoot, C. (2014). Shoot meristems of deciduous woody perennials: self-organization and morphogenetic transitions. Curr. Opin. Plant Biol. 17, 86-95. doi: 10.1016/j.pbi.2013.11.009

Pin, P. A., and Nilsson, O. (2012). The multifaceted roles of FLOWERING LOCUS T in plant development. Plant Cell Environ. 35, 1742-1755. doi: 10.1111/j.13653040.2012.02558.x 
Porto, D. D., Bruneau, M., Perini, P., Anzanello, R., Renou, J.-P., dos Santos, H. P., et al. (2015). Transcription profiling of the chilling requirement for bud break in apples: a putative role for FLC-like genes. J. Exp. Bot. 66, 2659-2672. doi: 10.1093/jxb/erv061

Porto, D. D., Falavigna, V. S., Arenhart, R. A., Perini, P., Buffon, V., Anzanello, R., et al. (2016). Structural genomics and transcriptional characterization of the Dormancy-Associated MADS-box genes during bud dormancy progression in apple. Tree Genet. Genomes 12, 46. doi: 10.1007/s11295-016-1001-3

Powell, L. E. (1987). "The Hormonal Control of Bud and Seed Dormancy in Woody Plants," in Plant Hormones and their Role in Plant Growth and Development, ed. P. J. Davies (Dordrecht: Springer), 539-552. doi: 10.1007/978-94-009-3585-3_28

Richards, C. L., Alonso, C., Becker, C., Bossdorf, O., Bucher, E., Colomé-Tatché, M., et al. (2017). Ecological plant epigenetics: evidence from model and nonmodel species, and the way forward. Ecol. Lett. 20, 1576-1590. doi: 10.1111/ele. 12858

Rinne, P., and Kaikuranta, P. (2001). The shoot apical meristem restores its symplasmic organization during chilling-induced release from dormancy. Plant J. 26, 249-264. doi: 10.1046/j.1365-313X.2001.01022.x

Rinne, P., Saarelainen, A., and Junttila, O. (1994). Growth cessation and bud dormancy in relation to ABA level in seedlings and coppice shoots of Betula pubescens as affected by a short photoperiod, water stress and chilling. Physiol. Plant. 90, 451-458. doi: 10.1111/j.1399-3054.1994.tb08801.x

Rinne, P. L., and van der Schoot, C. (1998). Symplasmic fields in the tunica of the shoot apical meristem coordinate morphogenetic events. Development 125 , 1477-1485. doi: 10.1016/S1369-5266(98)80057-5

Rinne, P. L., Welling, A., Vahala, J., Ripel, L., Ruonala, R., Kangasjärvi, J., et al. (2011). Chilling of Dormant Buds Hyperinduces FLOWERING LOCUS T and recruits GA-inducible 1,3-b-glucanases to reopen signal conduits and release dormancy in Populus. Plant Cell 23, 130-146. doi: 10.1105/tpc.110.08 1307

Ríos, G., Leida, C., Conejero, A., and Badenes, M. L. (2014). Epigenetic regulation of bud dormancy events in perennial plants. Front. Plant Sci. 5:247. doi: 10.3389/fpls.2014.00247

Rodriguez-A, J., Sherman, W. B., Scorza, R., Wisniewski, M., and Okie, W. R. (1994). "Evergreen" peach, its inheritance and dormant behavior. J. Am. Soc. Hortic. Sci. 119, 789-792.

Rohde, A., and Bhalerao, R. P. (2007). Plant dormancy in the perennial context. Trends Plant Sci. 12, 217-223. doi: 10.1016/j.tplants.2007.03.012

Rohde, A., Prinsen, E., De Rycke, R., Engler, G., Van Montagu, M., and Boerjan, W. (2002). PtABI3 impinges on the growth and differentiation of embryonic leaves during bud set in poplar. Plant Cell 14, 1885-1901. doi: 10.1105/tpc.003186

Romera-Branchat, M., Andrés, F., and Coupland, G. (2014). Flowering responses to seasonal cues: What's new? Curr. Opin. Plant Biol. 21, 120-127. doi: 10.1016/ j.pbi.2014.07.006

Romeu, J. F., Monforte, A. J., Sánchez, G., Granell, A., García-Brunton, J., Badenes, M. L., et al. (2014). Quantitative trait loci affecting reproductive phenology in peach. BMC Plant Biol. 14:52. doi: 10.1186/1471-2229-14-52

Rothkegel, K., Sánchez, E., Montes, C., Greve, M., Tapia, S., Bravo, S., et al. (2017) DNA methylation and small interference RNAs participate in the regulation of MADS-box genes involved in dormancy in sweet cherry (Prunus avium L.). Tree Physiol. 24, 1-13. doi: 10.1093/treephys/tpx136

Rubio, S., Donoso, A., and Pérez, F. J. (2014). The dormancy-breaking stimuli "chilling, hypoxia and cyanamide exposure" up-regulate the expression of $\alpha$-amylase genes in grapevine buds. J. Plant Physiol. 171, 373-381. doi: 10.1016/ j.jplph.2013.11.009

Ruttink, T., Arend, M., Morreel, K., Storme, V., Rombauts, S., Fromm, J., et al. (2007). A molecular timetable for apical bud formation and dormancy induction in poplar. Plant Cell 19, 2370-2390. doi: 10.1105/tpc.107.052811

Saito, T., Bai, S., Imai, T., Ito, A., Nakajima, I., and Moriguchi, T. (2015). Histone modification and signalling cascade of the dormancy-associated MADS -box gene, PpMADS 13-1, in Japanese pear (Pyrus pyrifolia) during endodormancy. Plant Cell Environ. 38, 1157-1166. doi: 10.1111/pce.12469

Saito, T., Bai, S., Ito, A., Sakamoto, D., Saito, T., Ubi, B. E., et al. (2013). Expression and genomic structure of the dormancy-associated MADS box genes MADS13 in Japanese pears (Pyrus pyrifolia Nakai) that differ in their chilling requirement for endodormancy release. Tree Physiol. 33, 654-667. doi: 10.1093/treephys/ tpt037
Sánchez-Pérez, R., Dicenta, F., and Martínez-Gómez, P. (2012). Inheritance of chilling and heat requirements for flowering in almond and QTL analysis. Tree Genet. Genomes 8, 379-389. doi: 10.1007/s11295-011-0448-5

Sasaki, R., Yamane, H., Ooka, T., Jotatsu, H., Kitamura, Y., Akagi, T., et al. (2011). Functional and expressional analyses of PmDAM genes associated with endodormancy in Japanese apricot. Plant Physiol. 157, 485-497. doi: 10.1104/ pp.111.181982

Schauer, S. E., Schlüter, P. M., Baskar, R., Gheyselinck, J., Bolaños, A., Curtis, M. D., et al. (2009). Intronic regulatory elements determine the divergent expression patterns of AGAMOUS-LIKE6 subfamily members in Arabidopsis. Plant J. 59, 987-1000. doi: 10.1111/j.1365-313X.2009.03928.x

Schwarz-Sommer, Z., Huijser, P., Nacken, W., Saedler, H., and Sommer, H. (1990). genetic control of flower development by homeotic genes in Antirrhinum majus. Science 250, 931-936. doi: 10.1126/science.250.4983.931

Seo, E., Lee, H., Jeon, J., Park, H., Kim, J., Noh, Y.-S., et al. (2009). Crosstalk between cold response and flowering in Arabidopsis is mediated through the flowering-time gene socl and its upstream negative regulator FLC. Plant Cell 21, 3185-3197. doi: 10.1105/tpc.108.063883

Shim, D., Ko, J.-H., Kim, W.-C., Wang, Q., Keathley, D. E., and Han, K.-H. (2014). A molecular framework for seasonal growth-dormancy regulation in perennial plants. Hortic. Res. 1:14059. doi: 10.1038/hortres.2014.59

Sieburth, L. E., and Meyerowitz, E. M. (1997). Molecular dissection of the AGAMOUS control region shows that cis elements for spatial regulation are located intragenically. Plant Cell 9, 355-365. doi: 10.1105/tpc.9.3.355

Singh, R. K., Maurya, J. P., Azeez, A., Miskolczi, P., Tylewicz, S., Stojkoviè, K., et al. (2018). A genetic network mediating the control of bud break in hybrid aspen. Nat. Commun. 9:4173. doi: 10.1038/s41467-018-06696-y

Singh, R. K., Svystun, T., AlDahmash, B., Jönsson, A. M., and Bhalerao, R. P. (2017). Photoperiod- and temperature-mediated control of phenology in trees a molecular perspective. New Phytol. 213, 511-524. doi: 10.1111/nph.14346

Smaczniak, C., Immink, R. G., Angenent, G. C., and Kaufmann, K. (2012). Developmental and evolutionary diversity of plant MADS-domain factors: insights from recent studies. Development 139, 3081-3098. doi: 10.1242/dev. 074674

Srinivasan, C., Dardick, C., Callahan, A., and Scorza, R. (2012). Plum (Prunus domestica) trees transformed with poplar FT1 result in altered architecture, dormancy requirement, and continuous flowering. PLoS One 7:e40715. doi: 10.1371/journal.pone.0040715

Tanino, K. (2004). Hormones and Endodormancy Induction in Woody Plants. J. Crop Improv. 10, 157-199. doi: 10.1300/J411v10n01_08

Tamaki, S., Matsuo, S., Wong, H. L., Yokoi, S., and Shimamoto, K. (2007). Hd3a protein is a mobile flowering signal in rice. Science 316, 1033-1036. doi: $10.1126 /$ science. 1141753

Theißen, G., Melzer, R., and Rümpler, F. (2016). MADS-domain transcription factors and the floral quartet model of flower development: linking plant development and evolution. Development 143, 3259-3271. doi: 10.1242/dev. 134080

Tränkner, C., Lehmann, S., Hoenicka, H., Hanke, M.-V., Fladung, M., Lenhardt, D., et al. (2010). Over-expression of an FT-homologous gene of apple induces early flowering in annual and perennial plants. Planta 232, 1309-1324. doi: 10.1007/s00425-010-1254-2

Tuan, P. A., Bai, S., Saito, T., Imai, T., Ito, A., and Moriguchi, T. (2016). Involvement of EARLY BUD-BREAK, an AP2/ERF transcription factor gene, in bud break in Japanese pear (Pyrus pyrifolia Nakai) lateral flower buds: expression, histone modifications and possible target genes. Plant Cell Physiol. 57, 1038-1047. doi: 10.1093/pcp/pcw041

Tuan, P. A., Bai, S., Saito, T., Ito, A., and Moriguchi, T. (2017). DormancyAssociated MADS-Box (DAM) and the abscisic acid pathway regulate pear endodormancy through a feedback mechanism. Plant Cell Physiol. 58, 13781390. doi: $10.1093 / \mathrm{pcp} / \mathrm{pcx} 074$

Tylewicz, S., Petterle, A., Marttila, S., Miskolczi, P., Azeez, A., Singh, R. K., et al. (2018). Photoperiodic control of seasonal growth is mediated by ABA acting on cell-cell communication. Science 360, 212-215. doi: 10.1126/science. aan8576

Ubi, B. E., Ban, Y., Shimada, T., Ito, A., Nakajima, I., Takemura, Y., et al. (2010). Molecular cloning of dormancy-associated MADS-box gene homologs and their characterization during seasonal endodormancy transitional phases of Japanese pear. J. Am. Soc. Hortic. Sci. 135, 174-182. 
Urrestarazu, J., Muranty, H., Denancé, C., Leforestier, D., Ravon, E., Guyader, A., et al. (2017). Genome-Wide association mapping of flowering and ripening periods in apple. Front. Plant Sci. 8:1923. doi: 10.3389/fpls.2017.01923

van Dyk, M. M., Soeker, M. K., Labuschagne, I. F., and Rees, D. J. G. (2010). Identification of a major QTL for time of initial vegetative budbreak in apple (Malus x domestica Borkh.). Tree Genet. Genomes 6, 489-502. doi: 10.1007/ s11295-009-0266-1

Varkonyi-Gasic, E., Moss, S. M., Voogd, C., Wang, T., Putterill, J., and Hellens, R. P. (2013). Homologs of FT, CEN and FD respond to developmental and environmental signals affecting growth and flowering in the perennial vine kiwifruit. New Phytol. 198, 732-746. doi: 10.1111/nph.12162

Velasco, R., Zharkikh, A., Affourtit, J., Dhingra, A., Cestaro, A., Kalyanaraman, A., et al. (2010). The genome of the domesticated apple (Malus $\times$ domestica Borkh.). Nat. Genet. 42, 833-839. doi: 10.1038/ng.654

Wang, D., Gao, Z., Du, P., Xiao, W., Tan, Q., Chen, X., et al. (2015). Expression of ABA metabolism-related genes suggests similarities and differences between seed dormancy and bud dormancy of peach (Prunus persica). Front. Plant Sci. 6:1248. doi: $10.3389 /$ fpls.2015.01248

Wareing, P. F. (1978). Abscisic acid as a natural growth regulator. Philos. Trans. R. Soc. Lond. B 284, 483-498. doi: 10.1098/rstb.1978.0084

Whittaker, C., and Dean, C. (2017). The FLC locus: a platform for discoveries in epigenetics and adaptation. Annu. Rev. Cell Dev. Biol. 33, 555-575. doi: 10.1146/annurev-cellbio-100616-060546

Wisniewski, M., Norelli, J., and Artlip, T. (2015). Overexpression of a peach CBF gene in apple: a model for understanding the integration of growth, dormancy, and cold hardiness in woody plants. Front. Plant Sci. 6:85. doi: 10.3389/fpls. 2015.00085

Wisniewski, M., Norelli, J., Bassett, C., Artlip, T., and Macarisin, D. (2011). Ectopic expression of a novel peach (Prunus persica) CBF transcription factor in apple (Malus $\times$ domestica) results in short-day induced dormancy and increased cold hardiness. Planta 233, 971-983. doi: 10.1007/s00425-011-1358-3

Wu, R., Tomes, S., Karunairetnam, S., Tustin, S. D., Hellens, R. P., Allan, A. C., et al. (2017a). SVP-like MADS box genes control dormancy and budbreak in apple. Front. Plant Sci. 8:477. doi: 10.3389/fpls.2017.00477

Wu, R., Wang, T., Warren, B. A. W., Allan, A. C., Macknight, R. C., and VarkonyiGasic, E. (2017b). Kiwifruit SVP2 gene prevents premature budbreak during dormancy. J. Exp. Bot. 68, 1071-1082. doi: 10.1093/jxb/erx014

Wu, R., Wang, T., Warren, B. A. W., Thomson, S. J., Allan, A. C., Macknight, R. C., et al. (2017c). Kiwifruit SVP2 controls developmental and droughtstress pathways. Plant Mol. Biol. 96, 233-244. doi: 10.1007/s11103-0170688-3

Wu, R. M., Walton, E. F., Richardson, A. C., Wood, M., Hellens, R. P., and Varkonyi-Gasic, E. (2012). Conservation and divergence of four kiwifruit SVPlike MADS-box genes suggest distinct roles in kiwifruit bud dormancy and flowering. J. Exp. Bot. 63, 797-807. doi: 10.1093/jxb/err304

Xiang, Y., Huang, C.-H., Hu, Y., Wen, J., Li, S., Yi, T., et al. (2017). Evolution of rosaceae fruit types based on nuclear phylogeny in the context of geological times and genome duplication. Mol. Biol. Evol. 34, 262-281. doi: 10.1093/ molbev/msw242

Yamane, H., Kashiwa, Y., Ooka, T., Tao, R., and Yonemori, K. (2008). Suppression subtractive hybridization and differential screening reveals endodormancyassociated expression of an SVP/AGL24-type MADS-box gene in lateral vegetative buds of Japanese apricot. J. Am. Soc. Hortic. Sci. 133, 708-716.

Yamane, H., Ooka, T., Jotatsu, H., Hosaka, Y., Sasaki, R., and Tao, R. (2011a). Expressional regulation of PpDAM5 and PpDAM6, peach (Prunus persica) dormancy-associated MADS-box genes, by low temperature and dormancybreaking reagent treatment. J. Exp. Bot. 62, 3481-3488. doi: 10.1093/jxb/er r028

Yamane, H., Ooka, T., Jotatsu, H., Sasaki, R., and Tao, R. (2011b). Expression analysis of PpDAM5 and PpDAM6 during flower bud development in peach (Prunus persica). Sci. Hortic. 129, 844-848. doi: 10.1016/j.scienta.2011. 05.013
Yamane, H., and Tao, R. (2015). "Functional characterization of Japanese apricot (Prunus mume) DORMANCY-ASSOCIATED MADS-box1 (PmDAM1), a paralog of PmDAM6, using Populus transformants," in Advances in Plant Dormancy, ed. J. V. Anderson (Cham: Springer International Publishing), 147-157. doi: 10.1007/978-3-319-14451-1_8

Yamane, H., Tao, R., Ooka, T., Jotatsu, H., Sasaki, R., and Yonemori, K. (2011c). Comparative analyses of dormancy-associated MADS-box genes, PpDAM5 and PpDAM6, in low- and high-chill peaches (Prunus persica L.). J. Jpn. Soc. Hortic. Sci. 80, 276-283. doi: 10.2503/jjshs1.80.276

Yarur, A., Soto, E., León, G., and Almeida, A. M. (2016). The sweet cherry (Prunus avium) FLOWERING LOCUS T gene is expressed during floral bud determination and can promote flowering in a winter-annual Arabidopsis accession. Plant Reprod. 29, 311-322. doi: 10.1007/s00497-016-0296-4

Yue, C., Cao, H., Hao, X., Zeng, J., Qian, W., Guo, Y., et al. (2017). Differential expression of gibberellin- and abscisic acid-related genes implies their roles in the bud activity-dormancy transition of tea plants. Plant Cell Rep. 37, 425-441. doi: 10.1007/s00299-017-2238-5

Zhang, L., Wang, Y., Zhang, X., Zhang, M., Han, D., Qiu, C., et al. (2012). Dynamics of phytohormone and DNA methylation patterns changes during dormancy induction in strawberry (Fragaria $\times$ ananassa Duch.). Plant Cell Rep. 31, 155-165. doi: 10.1007/s00299-011-1149-0

Zhang, Z., Zhuo, X., Zhao, K., Zheng, T., Han, Y., Yuan, C., et al. (2018). Transcriptome profiles reveal the crucial roles of hormone and sugar in the bud dormancy of Prunus mume. Sci. Rep. 8:5090. doi: 10.1038/s41598-018-23108-9

Zhao, C., Lang, Z., and Zhu, J.-K. (2015). Cold responsive gene transcription becomes more complex. Trends Plant Sci. 20, 466-468. doi: 10.1016/j.tplants. 2015.06.001

Zhao, K., Zhou, Y., Ahmad, S., Xu, Z., Li, Y., Yang, W., et al. (2018a). Comprehensive cloning of Prunus mume dormancy associated MADS-box genes and their response in flower bud development and dormancy. Front. Plant Sci. 9:17. doi: 10.3389/fpls.2018.00017

Zhao, K., Zhou, Y., Ahmad, S., Yong, X., Xie, X., Han, Y., et al. (2018b). PmCBFs synthetically affect PmDAM6 by alternative promoter binding and protein complexes towards the dormancy of bud for Prunus mume. Sci. Rep. 8:4527. doi: 10.1038/s41598-018-22537-w

Zhao, K., Zhou, Y., Li, Y., Zhuo, X., Ahmad, S., Han, Y., et al. (2018c). Crosstalk of PmCBFs and PmDAMs based on the changes of phytohormones under seasonal cold stress in the stem of Prunus mume. Int. J. Mol. Sci. 19:E15. doi: 10.3390/ijms19020015

Zhebentyayeva, T. N., Fan, S., Chandra, A., Bielenberg, D. G., Reighard, G. L., Okie, W. R., et al. (2014). Dissection of chilling requirement and bloom date QTLs in peach using a whole genome sequencing of sibling trees from an F2 mapping population. Tree Genet. Genomes 10, 35-51. doi: 10.1007/s11295-0130660-6

Zhong, W., Gao, Z., Zhuang, W., Shi, T., Zhang, Z., and Ni, Z. (2013). Genomewide expression profiles of seasonal bud dormancy at four critical stages in Japanese apricot. Plant Mol. Biol. 83, 247-264. doi: 10.1007/s11103-013-0086-4 Zhu, Y., Li, Y., Xin, D., Chen, W., Shao, X., Wang, Y., et al. (2015). RNA-Seqbased transcriptome analysis of dormant flower buds of Chinese cherry (Prunus pseudocerasus). Gene 555, 362-376. doi: 10.1016/j.gene.2014.11.032

Conflict of Interest Statement: The authors declare that the research was conducted in the absence of any commercial or financial relationships that could be construed as a potential conflict of interest.

Copyright (c) 2019 Falavigna, Guitton, Costes and Andrés. This is an open-access article distributed under the terms of the Creative Commons Attribution License (CC BY). The use, distribution or reproduction in other forums is permitted, provided the original author(s) and the copyright owner(s) are credited and that the original publication in this journal is cited, in accordance with accepted academic practice. No use, distribution or reproduction is permitted which does not comply with these terms. 